\title{
The regulation of E2F by PRB-family proteins
}

\section{Nicholas Dyson ${ }^{1}$}

Massachusetts General Hospital Cancer Center, Charlestown, M assachusetts 02129 USA

Much has been written about the functions of the E2F transcription factor and the product of the retinoblastoma tumor suppressor gene (pRB). These proteins have been described in terms that vary from "master regulators of cell cycle and differentiation" to "peripheral factors that lie outsi de the core cell cycle machinery." M ost often, pRB and E2F are described in short and simple terms as opposing molecules that control the $\mathrm{G}_{1}$ - to $\mathrm{S}$ phase transition.

There is an element of truth in each of these descriptions. E2F- and pRB-family proteins clearly play important roles in cell proliferation and differentiation. The extent to which they are master regulators or peripheral factors is a question of semantics, and these terms tell us more about the writer than the proteins. Perhaps the most important development in the E2F literature is the appreciation that E2F and pRB are not unique molecules with functions that can be defined in black and white terms. Instead, E2F and pRB represent families of related proteins that have diverse and occasionally contradictory activities. We now know a great deal about E2F complexes and pRB-family proteins and the emerging picture defies a one-line explanation. The fascinating variety of activities ascribed to various E2F complexes challenges us to place these into context and to find the right perspective.

This review is presented into two sections. The first section summarizes the tremendous progress into the composition and properties of E2F and the many interactions that coordinately regulate E2F-dependent transcription. The rapid growth in the size of the E2F literature hides the fact that several fundamental questions have not been fully answered. Because of this, the second section of this review details five unresolved issues that have been highlighted by recent publications. It is impossible to cover all of the relevant E2F literature in a single review and readers are referred to reviews by Farnham (1995); Sardet et al . (1997); Helin (1998); and Yamasaki (1998) for a comprehensive survey.

\section{An introduction to the families of E2F and DP proteins}

E2F has an important role in the control of cell proliferation in mammalian cells, in Drosophila, and presum-

1E-MAIL dyson@helix.mgh.harvard.edu; FAX (617) 726-7808. ably in many other eukaryotes. E2F is regulated in a cell cycle-dependent manner and fluctuations in E2F activity enable programs of gene expression to be coupl ed closely with cell cycle position.

Our models of E2F/pRB action have their roots in studies of adenovirus. E2F compl exes are defined by their ability to bind to a sequence el ement that was identified originally in the adenovirus E2 promoter (Kovesdi et al. 1987; La Thangue and Rigby 1987; Yee et al. 1987). M any different forms of E2F can be found in most cell types and these have been characterized largely by gel shift assays that employ cell extracts and oligonucleotides carrying consensus binding sites. E2F complexes are readily resolved into so-called "free E2F" and "complexed E2F." Initial studies of E2F showed that E2F-dependent transcription is stimulated by adenovirus E1A and this activation correlates with the appearance of free E2F (Bagchi et al. 1990). The components of most E2F complexes have been identified through the addition of specific antibodies. The discovery that pRB is a component of complexed E2F (Bagchi et al. 1991; Bandara and La Thangue 1991; Chellappan et al. 1991; Chittenden et al. 1991) enabled studies of E2F to be linked with genetic studies implicating pRB binding in E1A-mediated transformation (Whyte et al. 1988, 1989). When pieced together these findings suggested that E2F is regulated through its association with pRB and that the liberation of E2F could be a key element of E1A's oncogenic properties. Further studies have shown that activation of E2F-dependent transcription promotes cell cycle progression and Sphase entry. These properties suggested a simple model in which pRB restricts cell cycle progression by restraining E2F and the release of E2F from pRB drives cell proliferation.

\section{Free E2F}

Free E2F, the smal lest E2F compl exes, are heterodimers containing a subunit encoded by the E2F gene family and a subunit encoded by the DP family of genes. To date, six E2F genes and two DP genes have been found in mammalian cells (Fig. 1). Drosophila contain at least one DP gene and two E2F genes, and other homologs have been found in Caenorhabditis elegans, chicken, and Xenopus (Dynlacht et al. 1994a; Girling et al. 1994; Ohtani and Nevins 1994; Phil pott and Friend 1994; Hao et al. 1995; 


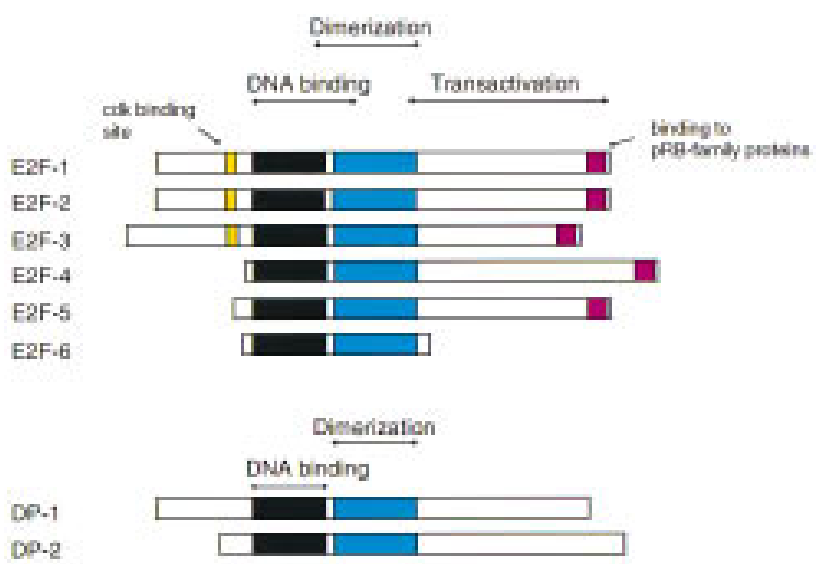

Figure 1. The organization of the six mammalian E2F genes and two DP genes. E2F and DP proteins share a conserved DN Abinding and dimerization domain. The relative positions of pRB-binding domains and cdk-binding domains are al so shown. The references for these genes are E2F-1 (Helin et al. 1992; Kaelin et al. 1992; Shan et al. 1992); E2F-2 (Ivey-Hoyle et al. 1993; Lees et al. 1993); E2F-3 (Lees et al. 1993); E2F-4 (Beijersbergen et al. 1994; Ginsberg et al. 1994; Sardet et al . 1995); E2F-5 (Hijmans et al. 1995; Sardet et al. 1995); E2F-6 (Morkel et al. 1997; Cartwright et al. 1998; Trimarchi et al. 1998); DP-1 (Girling et al. 1993); DP-2 (Ormondroyd et al. 1995; Wu et al. 1995; Zhang and Chellappan 1995; Rogers et al. 1996). N ote that the second mammalian DP gene to be isolated has also been called DP-3 because of its homology to Xenopus DP-3 (Ormondroyd et al . 1995), and the sixth E2F family member was first named EMA (Morkel et al. 1997).

Pasteau et al. 1995; D. Huen, unpubl.). E2F and DP proteins contain highly conserved DNA-binding domains and dimerization domains (Hel in 1998). The carboxy-terminal portions of E2F-1, E2F-2, E2F-3, E2F-4, and E2F-5 contain a potent transactivation domain but no equivalent activity has been found in E2F-6 nor in DP proteins. Although E2F and DP proteins activate E2F-dependent transcription in a synergistic manner, DP subunits appear to activate transcription indirectly by potentiating the acti vity of the E2F subunit (Bandara et al. 1993; Hel in et al. 1993b; Krek et al. 1993). E2F-6, the most recently discovered member of the E2F-family, is proposed to repress E2F-dependent transcription (Morkel et al. 1997; Cartwright et al. 1998; Trimarchi et al. 1998).

Rel atively little is known about the specific properties of the individual mammalian E2Fs. The appearance of tissue-specific defects in E2F-1 (Field et al. 1996; Y amasaki et al. 1996) or E2F-5 deficient mice (Lindeman et al. 1998) suggests that individual E2Fs have functions that are either unique or restricted to certain cell types. The literature on expression patterns of E2Fs is quite small. DP-1 and E2F-1 are broadly, but not uniformly, expressed during mouse embryogenesis (Tevosian et al. 1996). Similar analysis of E2F-2, E2F-4, and E2F-5 expression suggest that E2F-2 and E2F-4 are expressed more highly in proliferating cells whereas E2F-5 is more evident in some differentiating cells including the choroid plexus (Dagnino et al. 1997a,b; Lindeman et al. 1998). The spe- cific inactivation of each of the murine E2F- and DPfamily members is of clear importance and is being attempted in several groups. Presumably, these studies will reveal the unique roles of individual E2F components.

It is widely anticipated that different E2F heterodimers will be found to regulate different subsets of E2F target genes. When overexpressed, E2F-1, E2F-2, E2F-3, E2F-4, and $\mathrm{E} 2 \mathrm{~F}-5$ induced the expression of a panel of E2F-target genes to differing degrees and in slightly different patterns (DeGregori et al. 1997). In vitro binding assays show that E2F heterodimers can bind to a variety of E2Frelated sequences and that heterodimers sel ect different sequence variants from a random pool (Tao et al. 1997). Possibly, the promoter context of E2F binding sites may be very important in sel ecting specific forms of E2F. The physical interactions between Sp-1 and E2F-1, E2F-2, or E2F-3 (Karlseder et al . 1996; Lin et al . 1996) and p107 and Sp-1 (Datta et al. 1995) may be examples of interactions that allow cooperative binding by specific types of E2F complexes. Despite these indications, however, it has not yet been possible to match individual forms of E2F with their specific targets inside the cell. It is unclear whether this is because there is extensive redundancy between E2Fs or for the lack of an assay that can reveal the specificity.

\section{Complexed E2F}

The complexed forms of E2F contain E2F/DP heterodimers that are stably bound to a member of the pRB family of proteins, pRB, p107, and p130 (Bagchi et al. 1991; Bandara and La Thangue 1991; Chellappan et al. 1991; Chittenden et al. 1991; C ao et al. 1992; Devoto et al. 1992; Shirodkar et al. 1992; Cobrinik et al. 1993). In many different experimental systems the overexpression of pRB, p107, or p130 inhibits E2F-dependent transcripti on (for examples, see Hiebert et al. 1992; Flemington et al. 1993; Helin et al. 1993a; Zamanian and La Thangue 1993; Dynlacht et al. 1994). Whereas no specificity has been described for interactions between E2F and DP subunits nor between DP and pRB-family proteins, the E2F proteins show strong preferences for specific pRB-family members: E2F-1, E2F-2, and E2F-3 bind almost exclusively to pRB; E2F-5 associates with p130; E2F-4 binds with high affinity to p107 and p130 but also associates with PRB in some cell types (for a detailed review, see Sardet et al. 1997). A short, highly conserved domain near the carboxyl terminus of the E2F proteins mediates binding to pRB-family proteins (Helin et al. 1993a). This binding domain is embedded in the transactivation domain of the E2F subunit and the overlapping arrangement of these two domains provides a simple model to explain how the association of pRB, p107, or p130 with E2F might inhibit E2F-dependent transcription. E2F-6 lacks sequences homologous to the $\mathrm{pRB}$-binding domain of E2F-1 and does not appear to be regulated in an analogous manner (Morkel et al. 1997).

pRB, p107, and p130 are expressed broadly but associate with E2F during different portions of the cell cycle 
Table 1. Specific types of E2F/pRB-family protein complexes prevalent during the cell cycle

\begin{tabular}{lll}
$\begin{array}{l}\text { pRB family } \\
\text { member }\end{array}$ & \multicolumn{1}{c}{ Protein } & $\begin{array}{c}\text { Cell cycle } \\
\text { stages }\end{array}$ \\
\hline pRB & E2F-1, $-2,-3,-4$ & $\mathrm{G}_{0}, \mathrm{G}_{1}, \mathrm{~S}$ \\
p107 & E2F-4 & $\mathrm{G}_{1}, \mathrm{~S}^{*}, \mathrm{G}_{2}{ }^{*}$ \\
p130 & E2F-4, -5 & $\mathrm{G}_{0}, \mathrm{G}_{1}$ \\
\hline
\end{tabular}

Summarized are stages of the cell cycle when the pRB-family member is most readily detected in E2F complexes and the type of E2F proteins that associate with the endogenous proteins. Each of these complexes al so contains a DP protein. The asterisk $(*)$ indicates that the S-phase p107 complexes also contain stoichiometric levels of cdks; the function of this association is not known.

(Table 1). Although the precise pattern varies, p130/E2F complexes are found primarily in quiescent or differentiated cells and p107/E2F complexes are most prevalent in $S$ phase cells but can al so be found in $G_{1}$. pRB/E2F complexes can be found in quiescent or differentiated cells, but are most evident as cells progress from $\mathrm{G}_{1}$ into S phase (see, e.g., Shirodkar et al. 1992; Ikeda et al. 1996; Moberg et al. 1996; or Sardet et al. 1997, for a detailed review).

\section{E2F-binding sites mediate both transcriptional activation and repression}

What we know about E2F-dependent transcription is gathered al most entirely from studies in tissue culture cells. It is important to remember that most of the current models rely on the assumption that the effects seen when E2F-, DP-, and pRB-family proteins are overexpressed reflect the properties of the endogenous proteins. In the initial models of E2F action, the activation of E2Fdependent transcription was proposed to be caused by the unmasking of an activation domain in the E2F complex. This view was turned upside down by the discovery that E2F/pRB complexes can actively repress transcription (Hamel et al. 1992; Weintraub et al. 1992). The discovery of the $\mathrm{pRB} / \mathrm{E} 2 \mathrm{~F}$ repressor has raised a debate that is still not completely settled. Should we think of E2Fbinding sites as activators of gene expression in S phase, or as elements that confer cell cycl e regulated repression in $\mathrm{G}_{0} / \mathrm{G}_{1}$ ?

Targets for E2F were initially suggested by the observation of consensus E2F-binding sequences in promoter regions. It is now apparent that a large number of promoters contain potential E2F-binding sites and, in a few cases, mutation of the binding site has confirmed that E2F is critical for cell cycle-regulated transcription. Such studies assume that the behavior of small fragments of genomic DN A will faithfully reproduce the properties of the endogenous genes. To date, there are no studies in which the E2F-binding site has been specifically mutated in its natural setting, in the promoter of an endogenous gene. This will be an important test of current models, and the absence of this type of data is a substantial ca- veat, given the important role of chromatin structure in the regulation of gene expression.

Mutational analysis of putative E2F-binding sites in relatively small fragments of genomic DN A suggest that E2F-binding sites regulate gene expression in different ways in different promoter contexts. The evidence leading to these models is described in the sections bel ow. It is generally believed that the different properties of individual E2F-binding sites reflect the binding of different types of E2F complexes. To summarize a great deal of bi ochemical data, there appear to be three generic types of E2F complexes (Fig. 2): activator E2F complexes, in which the E2F activation domain promotes transcription; inhibited E2F complexes, in which the activation domain is masked by pRB-family proteins to give a complex that is essentially inert; and repressor E2F complexes, in which RB-family proteins that are recruited to the DN A by E2F assemble a repressor activity. Each of these activities can be demonstrated in carefully designed assays but the relative contributions that they make to the normal functions of E2F are not known. At the moment, making a connection between the binding of individual E2F complexes and changes in gene expression requires a leap of faith. It has not been technically possible to identify the components of an individual E2F complex bound at the promoter of an endogenous gene. Because of this, connections drawn between specific types of E2F and individual target genes should be regarded as informed guesswork.

With these caveats in mind, the activities of E2F complexes have been examined in great detail on a variety of different promoters. These studies provide a strong framework from which the potential functions of E2F derive. Both E2F-mediated activation and repression occur in different settings and the current evidence indi-
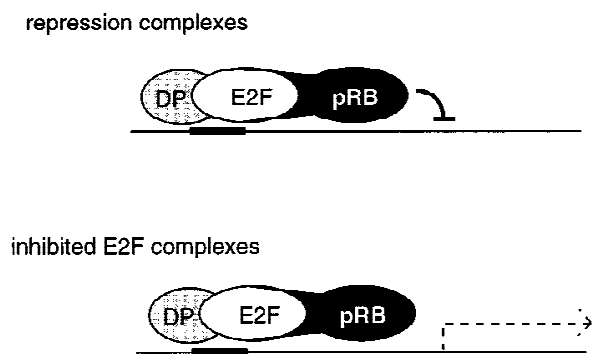

actlvating complexes

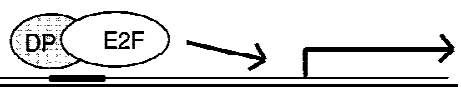

Figure 2. Transcriptional studies suggest that there are three generic types of E2F complexes: activator E2F complexes, inhibited E2F complexes, and repressor E2F complexes in which RB-family proteins that are recruited to DNA by E2F assemble a repressor activity. The level of gene expression that occurs when inhibited E2F complexes are bound will depend on the presence of other transcriptional activators. 
cates that both processes are likely to be functionally significant.

\section{E2F as a transcriptional activator}

Mutation of E2F-binding sites in the dihydrofolate reductase (DHFR) promoter indicates that E2F binding is required to activate DHFR expression during $G_{1}$ to $S$ progression (Means et al. 1992; Wade et al. 1992). Sp-1 and E2F bind cooperatively to the DHFR promoter (Karlseder et al. 1996) and the relative position of E2Fand Sp-1-binding sites is important for cell cycle regulation of promoter activity (Fry et al. 1997). The view that E2F is a transcriptional activator is supported by experiments showing that E2F proteins activate transcription of simple reporter constructs that contain multiple E2Fbinding sites (Helin et al. 1992; Shan et al. 1992), by the fact that E2F proteins contain conserved domains that activate transcription when transferred to other DNA binding domains (Kaelin et al. 1992), and by studies showing a strong correlation between the ability of E2F to activate transcription and to drive cell cycle progression (Johnson et al. 1993; Shan and Lee 1994; Qin et al. 1995). Precisely how E2F activates transcription is not known. At least three different mechanisms have been suggested. In vitro, E2F-1 can bind to TBP (Hagemeier et al. 1993; Emili and Ingles 1995). Biochemical studies show that the transcriptional activation domain of E2F-1 can interact with CBP (Trouche and Kouzarides 1996), potentially recruiting histone acetylase activity to the promoter. Consistent with this type of model, the overexpression of CBP potentiates transcriptional activation by E2F-1. Alternatively the ability of E2F complexes to bend DN A may be important for transcriptional activation (Cress and Nevins 1996). Although each of these mechanisms are possible there is no definitive data to distinguish between these or other models.

\section{E2F-mediated repression}

In contrast to the DHFR promoter, the mutation of E2F binding sites in the B-myb, E2F-1, E2F-2, cyclin E, and cdc2 promoters increases the activity of these promoters during $\mathrm{G}_{0} / \mathrm{G}_{1}$ (Dalton 1992; Lam and Watson 1993; Hsiao et al. 1994; Johnson et al. 1994b; Neuman et al. 1994; Ohtani et al. 1995; Geng et al. 1996; Sears et al. 1997; for other examples, see Helin 1998). Here the E2Fbinding sites appear to act as repressor elements during $\mathrm{G}_{1}$ and gene expression results from the rel ease of repression. In vivo footprinting of the E2F-binding sites in the B-myb promoter (Zwicker et al. 1996) and of potential E2F-binding sites in the cdc2 (T ommasi and Pfeifer 1995) and cyclin A promoters (Huet et al . 1996) indicated that these sites are occupied in $G_{0} / G_{1}$. These footprints are strongly decreased during $\mathrm{G}_{1}$-to-S progression and the E2F sites appear to be largely unoccupied at times when the genes are most highly transcribed. Although it is possible that all forms of E2F do not footprint equally, these results are consistent with the idea that activation of gene expression is due in large part to the loss of repressor complex. The view of E2F/pRB complexes as active repressors was first suggested by studies showing that the overexpression of $\mathrm{pRB}$ represses the expression of E2F-regulated genes (Hamel et al . 1992), and by experiments showing that the insertion of E2F binding sites into synthetic promoters allows repression of these promoters by pRB-family proteins (Weintraub et al. 1992). This model is strongly supported by studies showing that $\mathrm{pRB}$ represses transcription when fused to a heterologous DNA-binding domain (Adnane et al. 1995; Bremner et al. 1995; Sellers et al. 1995; Weintraub et al. 1995).

Because the binding site for pRB family proteins is embedded in the transcription activation domain of E2F proteins, pRB family proteins are thought to inactivate E2F by physically blocking the action of this domain. This would be sufficient to explain the cell cycle regulation of promoters such as DHFR where the E2F-binding sites are required to activate transcription. However additional processes are required to explain how E2F complexes become dominant repressors in $\mathrm{G}_{1}$. pRB contains distinct surfaces that enable it to bind to E2F and to bind to a different group of proteins that contain an LXCXE motif (Fattaey et al. 1993; Lee et al. 1998). Indeed, pRB can act as a bridge to form trimolecular complexes (Fattaey et al. 1993; Welch and Wang 1993). It is thought that pRB-family proteins that are recruited to DNA by E2F use a second binding site to repress transcription. The list of pRB-associated proteins in the literature includes hBrm and BRGl (Dunai ef et al. 1994; Singh et al. 1995), proteins that are components of mammalian SWI2/SN F complexes. hBrm and BRG1 contain LXCXE-rel ated sequences and are reported to cooperate with pRB in growth suppression (Dunai ef et al. 1994), and in repression of E2F-1 dependent transcription (Trouche et al. 1997). RbA p48, one of the first pRB-binding proteins isolated (Qian et al . 1993), was subsequently shown to associate with histone deacetylases (T aunton et al. 1996). Recent reports show that histone deacetylase activity is physically associated with pRB (Brehm et al. 1998; Magnaghi-Jaulin et al. 1998; Luo et al . 1998) and that this activity is important for pRB's repressor activities. Inhibitors of histone deacetylase interfere with the ability of pRB to repress E2F-dependent transcription. The recruitment of histone deacetylase to E2F-regulated promoters by $\mathrm{pRB}$ is proposed to repress transcription through changes in chromatin structure. It is not certain whether E2F/pRB/histone deacetylase repressor complexes play a critical role in E2F regulation in proliferating cells or whether these complexes function primarily during cell cycle exit and act in quiescent or differentiated cells.

\section{The activation of E2F-dependent transcription}

Because the activation of E2F-dependent transcription is linked with cell transformation and proliferation, the events leading to el evated E2F activity have been investigated in depth. This section summarizes the different 
types of regulation that have been proposed to contribute to the activation process. Although pRB is the best known regulator of E2F, the activation of E2F-dependent transcription is not the result of a single step but involves a series of changes in the composition, synthesis, and localization of E2F complexes (Fig. 3). The functional impact of these changes can be demonstrated in overexpressi on experiments. However, future studies are needed to determine the relative importance of the different tiers of regulation in the control of endogenous E2F activity.

The activation of E2F-dependent transcription has been studied primarily in systems in which quiescent cells are stimulated to enter the cell cycle. The majority of nuclear E2F complexes in quiescent or differentiated cells are bound to pRB-family proteins. When cells are stimulated to enter S phase, pRB-family proteins become phosphorylated and there is an accumulation of free E2F (Mudryj et al. 1991; Chittenden et al. 1993). This change correlates with the activation of E2F-dependent transcription and, conceivably, both the appearance of free
E2F and the disappearance of complexed E2F may contribute to the increase in expression of target genes.

\section{Phosphorylation of pRB-family members}

The disruption of pre-existing E2F complexes is attributed primarily to the phosphorylation of pRB-family proteins by cyclin-dependent kinases (cdks). pRB, p107, and p130 each contain multiple cdk phosphorylation sites and the hyperphosphorylated forms of pRB and p130 have very low affinity for E2F. Phosphorylated p130 appears to betargeted for degradation and the level s of p130 fall rapidly when quiescent cells are stimulated to enter the cell cycle (Smith et al. 1996). pRB phosphorylation has been studied in great detail. There appear to be at least two different stages in pRB phosphorylation, with cyclin D-dependent kinases acting first, and cyclin E- or cyclin A-dependent kinases acting later (for review, see Mittnacht 1998). E2F binding can be inhibited by the phosphorylation of several different clusters of sites on pRB (Knudsen and Wang 1997). Several studies have

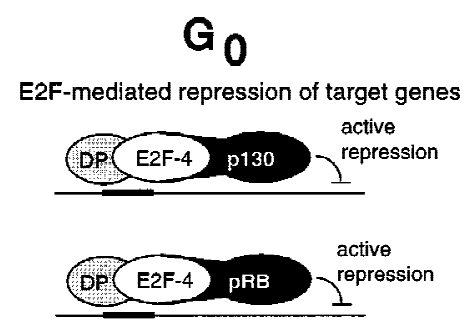

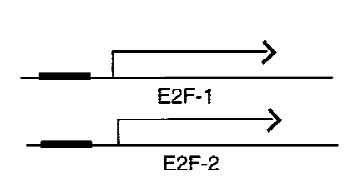

Synthesis of new E2F's

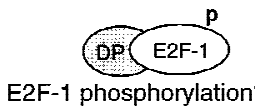

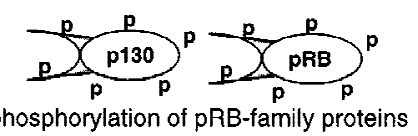

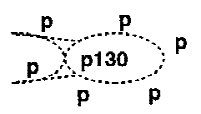

degradation of $p 130$

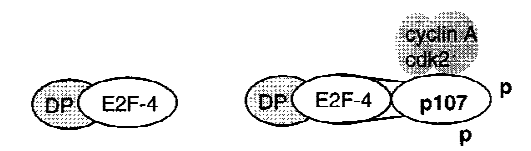

relocalization of E2F complexes to the cytoplasm

\section{S-phase}

De-repression and activated transcription of E2F target genes

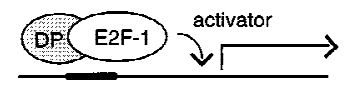

$\longrightarrow$

Figure 3. Multiple changes in the composition and location of E2F complexes are observed as cells leave quiescence and enter $\mathrm{S}$ phase. E2F-4 is the most prominent form of E2F found in quiescent cells, and in these cells most E2F-binding sites appear to be occupied by complexes that actively repress transcription. Cell cycle entry correl ates with the loss of repressor complexes and the accumulation of free E2F. On some promoters, gene induction appears to be due to the loss of repression. In other cases, E2F complexes are required for activation (illustrated here by E2F-1). The relative contribution of each individual process to the activation of E2F-dependent transcription is unknown and may vary between promoters. 
found that $\mathrm{pRB} / \mathrm{E} 2 \mathrm{~F}$ compl exes persist in $\mathrm{S}$ phase and can even be found in populations of $\mathrm{G}_{2}$ phase cells (Schwarz et al. 1993). The function of these E2F complexes, at times when cdks are active and E2F target genes are fully induced, is not understood.

\section{Phosphorylation of E2F-1}

In addition to the phosphorylation of $\mathrm{pRB}$, it is possible that phosphorylation of E2F-1 may al so disrupt pRB/E2F complexes. In vitro phosphorylation of E2F-1 on Ser-332 and Ser-337 prevents it from binding to pRB (Fagan et al . 1994). Potentially such phosphorylation may allow pRB/ E2F-1 complexes to be disrupted without the need for pRB phosphorylation, but this mechanism of activation has not yet been demonstrated in vivo.

\section{Changes in the subcellular localization of specific} E2F complexes

E2F-4 contributes the bulk of E2F DNA-binding activity in extracts of tissue culture cells. While the levels of E2F-4 protein do not change rapidly, substantial changes in the subcellular location of E2F-4 have been observed during the cell cycle (Lindeman et al . 1997; M üller et al. 1997; Verona et al . 1997). E2F-4 polypepti des are found in both the nucleus and cytoplasm of quiescent cells but relocate almost entirely to the cytoplasm once cells reach $S$ phase. Thus p107/E2F-4 complexes, the most abundant E2F complexes detected in extracts of S-phase cells, are proposed to be located primarily in the cytoplasm. The mechanisms governing the relocation of E2F-4 have not been elucidated in full. When it is overexpressed E2F-4 is largely cytoplasmic, but it can be driven into the nucleus by the coexpression of DP-2, p107, or p130 (Magae et al. 1996; Lindeman et al. 1997). Potentially the DP-dimerization partner may be important for this process. Four alternative spliced forms of DP-2 have been described. When overexpressed, two of these forms were largely cytopl asmic, whereas two others were nuclear (de la Luna et al. 1996). This raises the possibility that the expression of specific DP proteins may be used to control E2F localization. As the cytoplasmic relocation of endogenous E2F-4 correlates with the activation of E2F-responsive genes, the relocation of E2F-4 may be a mechanism to prevent repression of target genes by E2F-4-containing complexes.

\section{Synthesis of new E2Fs}

In addition to the release of E2F from pre-existing complexes, new synthesis of specific E2Fs al so contributes to appearance of free E2F. The transcription of E2F-1 and E2F-2 is strongly induced as cells progress from $G_{0}$ to $S$ phase. E2F-binding sites pl ay important roles in the regulation of the E2F-1 promoter, mediating transcriptional repression in $G_{0} / G_{1}$, and at least in some assays, contributing to full induction in $\mathrm{G}_{1} / \mathrm{S}$ (Hsiao et al. 1994; Johnson et al. 1994b; Neuman et al. 1994). Both E2Fbinding sites and E-box sequences, which can respond to
$\mathrm{C}-\mathrm{Myc}$, are important for the cell cycle regulation of the E2F-2 promoter (Sears et al . 1997). Potentially, the E2F-2 promoter may allow some coordination between the induction of Myc- and E2F-dependent transcription. As quiescent cells typically contain high levels of p130/E2F but low levels of E2F-1, it is proposed that there is a cascade of E2F activation in which the rel ease of E2F-4 or E2F-5 from p130 (or pRB) repressor compl exes al lows the expression of E2F-1 and E2F-2. The levels and DNAbinding activity of E2F-3 are cell cycle regulated and increase during S-phase entry (Leone et al. 1998), however the E2F-3 promoter has not been mapped and the regulation of E2F-3 is poorly understood. When overexpressed, E2F-1, E2F-2, and E2F-3 are more potent transcriptional activators than E2F-4 or E2F-5 (Lukas et al. 1996; DeGregori et al. 1997) and this may lead to elevated expression of other E2F-target genes. The specific targets of the newly synthesized E2F proteins are not known. It is unclear whether E2F-1, E2F-2, or E2F-3 will bind to unoccupied E2F sites or whether they replace pre-existing E2F complexes at target promoters. It is tempting to suggest that new E2F synthesis enables the overall level of E2F to exceed that of pRB-family proteins. However, this model is far from proven. Indeed E2F binding sites have also been found in the PRB and p107 promoters (Zhu et al . 1995) and the rise in level s of p107 that occurs when cells enter S phase runs counter to this model (Beijersbergen et al. 1995). Unfortunately, the total relative levels of E2F- and RB-family proteins have not been determined with any confidence in any experimental system.

One important and often overlooked quirk of the E2F literature is that most studies of the cell cycle regulation of E2F use quiescent cells that are stimulated to enter the cell cycle. Much less is known about the regulation of E2F activity in actively cycling cells or during cell cycle exit. E2F regulation may be quite different in these settings. In some cell types, pRB/E2F complexes are most abundant when cells are induced to differentiate, suggesting that pRB's role may be especially important during this process (Ikeda et al. 1996). In contrast to the dramatic changes in E2F complexes that occur when serum-starved cells are stimulated to enter the cell cycle, very few changes are seen in rapi dly di viding cells (Smith et al. 1996; Leone et al. 1998). Recent studies using REF52 cells show that there is a large number of genes whose expression can be induced by E2F, and whose expression increases when quiescent cells are stimulated to enter the cell cycle, yet only a small subset of these targets have cell cycle-regulated expression patterns in actively proliferating cells (Leone et al. 1998). This subset of genes includes cdk2, cdc6, cyclin E, Mcm2, and Mcm6 (Leone et al . 1998). In this study the DN A-binding activity of both E2F-1 and E2F-3 was induced during $\mathrm{G}_{0^{-}}$ to-S progression, but the periodic expression of target genes in cycling cells correlated with changes in the DNA-binding activity of E2F-3. The microinjection of antibodies to E2F-3 reduced S-phase entry suggesting that at least in REF52 cells, E2F-3 is an important regulator of the $\mathrm{G}_{1}$ - to S-phase transition. These observations 
emphasize that E2F regulation differs greatly depending whether cells are moving from $M$ to $G_{1}$ to $S$ phase, or from $G_{0}$ to $G_{1}$ to $S$ phase.

\section{The inactivation of E2F}

Depending on one's perspective, the inactivation of E2F could be regarded as the most important regulatory step. If pRB association were the sole determinant of E2F activity, E2F-dependent transcription would be expected to be constitutive from the time that $\mathrm{pRB}$ is hyperphosphorylated (S phase) until it is dephosphorylated (mitosis), and this is clearly not the case. Although the downregulation of E2F-dependent transcription has not been studied in great detail, the expression of some E2F-target genes decreases as cells leave $S$ phase (see, e.g., M eans et al. 1992; Lam and Watson 1993; Leone et al. 1998). M oreover, the expression of constitutively active, mutant forms of E2F-1 or DP-1 caused an accumulation of cells in $\mathrm{S}$ phase and eventually led to apoptosis (Krek et al. 1995). Taken together, these results imply that a decrease in E2F activity is required for cells to exit $\mathrm{S}$ phase and that this is separate from pRB regulation. Three processes have been implicated in the inactivation of E2F.

\section{E2F/DP phosphorylation}

E2F-1, E2F-2, and E2F-3 contain a conserved motif that mediates stable association with cyclin A/cdk2 or cyclin E/cdk2 (Krek et al. 1994). Kinases bound through this domain to a E2F-1/DP-1 dimer phosphorylate both the E2F-1 and DP-1 subunits and inhibit DNA-binding activity (Dynlacht et al. 1994; Krek et al. 1994, 1995; Xu et al. 1994; Kitagawa et al. 1995). The expression of mutant E2F-1 proteins lacking the cdk-binding site, or mutant DP-1 proteins lacking the major phosphorylation sites, generated stable E2F complexes and arrested cells in S phase (Krek et al. 1995). Unlike cyclin A/cdk2, the action of cyclin E/cdk2 on E2F-1/DP-1 dimers has little effect on DNA-binding activity (Dynlacht et al. 1994). The basis for the distinction between the cdks is not completely clear, however, as cyclin E/cdk2 kinase is activated before cyclin A/cdk2, this difference may hel $p$ to establish a window in the cell cycle where E2F is active (Dynlacht et al. 1994).

Changes in E2F/DP phosphorylation have also been linked to the down-regulation of E2F activity during adipogenesis. In a tissue culture model system, increased phosphorylation of DP-1 and E2F-1 correlated with cell cycle withdrawal during adipocyte differentiation (AItiok et al. 1997). The increase in DP-1 phosphorylation may be a result of a decrease in the level of the PP2A catalytic subunit as the addition of purified PP2A cataIytic subunit reversed this effect and restored DN A-binding activity.

\section{Degradation of free E2F}

U biquitin-directed degradation of free E2F may also contribute to the inactivation of E2F in S phase. When over- expressed, E2F-1 and E2F-4 are degraded by the ubiquitin-proteosome pathway (Hateboer et al. 1996; Hofmann et al. 1996). Sequences in the transactivation domain of the E2F proteins are important for this process and the stability of E2F-1 or E2F-4 is greatly enhanced by association with $\mathrm{pRB}, \mathrm{p} 107$, or $\mathrm{p} 130$. Such regulation may augment the stability of E2F-repressor complexes and may provide a means to attenuate the activity of free E2F. This model is highly attractive but future studies are needed to determine the role of ubiquitin-directed degradation in the overall control of endogenous E2F proteins.

\section{E2F-repressors}

A third potential mechanism is suggested by the observation that E2F-6 is a repressor of E2F-dependent transcription (Morkel et al. 1997; Trimarchi et al. 1998). The finding that E2F-6 has a lower affinity for DNA than other E2Fs raises the possi bility that E2F-6 might bind to E2F-target promoters and repress their transcription when the binding acti vity of other E2Fs is decreased. The cell cycle activity of E2F-6 is not yet known. In some studies the overproduction of E2F-6 resulted in the accumulation of S-phase cells (Cartwright et al. 1998; J. Lees, pers. comm.). In other studies the overexpression of E2F-6 had no effect on asynchronously growing NIH3T 3 cells but prevented quiescent cells from entering $S$ phase, raising the possibility that E2F-6 may act on the entry or exit of cells from the cell cycle (S. Gaubatz and D.M. Livingston, in prep.). Ultimately, the complete down-regulation of E2F-dependent transcription in quiescent cells is likely to require the assembly of active repressor complexes, such as those containing histone deacetylases. The events regulating the formation of E2F-repressor complexes are extremely important and completely unknown.

\section{The consequences of elevated E2F activity-ectopic S-phase entry and apoptosis}

One of the most striking properties of E2F proteins is their ability to drive cells into $S$ phase. This property is central to most models of E2F function and was first shown for E2F-1 (Johnson et al. 1993). Similar results have been reported for E2F-2, E2F-3, E2F-4, E2F-5, and dE2F (Asano et al. 1996; Du et al. 1996; Lukas et al. 1996). E2F-1 overexpression overrides many different types of cell cycle arrest including the effects of p16, p21, p27, $\gamma$-irradiation, TGF $\beta$, and dominant-negative cdk2 and is able to drive quiescent cells into $S$ phase (Johnson et al. 1993; DeGregori et al . 1995a,b; Schwarz et al . 1995; Lukas et al. 1996; Mann and Jones 1996). However, in vivo studies show that some arrested or differentiating cells are not readily driven into S phase by high levels of E2F (Asano et al. 1996; Du et al. 1996). Overexpression of E2F in transgenic animals disrupts the developmental regulation of the cell cycle. The elevation of E2F activity dissociates the coordination of cell growth and proliferation during Drosophila wing devel opment ( $N$ eufeld et al. 
1998). In transgenic mice, the overexpression of E2F-1 promotes cell proliferation and blocks some aspects of differentiation (Guy et al. 1996).

Mutational studies show that E2F-1's ability to drive cells into S phase requires its DP-binding, DN A-binding, and transactivation domains, and there is a strong correlation between the ability of E2F to activate transcription of target genes and its ability to promote DN A synthesis (Johnson et al. 1993; Qin et al . 1994). It is believed that E2F promotes $S$ phase by el evating the expression of rate-limiting genes. It is conceivable that E2F has a more di rect role in the initiation of DN A synthesis but there is no evidence for such an activity. Consistent with the idea that E2F promotes cell proliferation, E2F-1, E2F-4, and DP-1 have all been reported to score in transformation assays, either alone or in combination with an acti vated ras gene (Bei jersbergen et al. 1994; Ginsberg et al . 1994; Johnson et al. 1994a; Singh et al. 1994; Jooss et al. 1995; Xu et al. 1995).

There is a major caveat to the idea that increased E2F activity automatically leads to cell proliferation. Overexpression of E2F-1 or dE2F in normal cells causes high levels of apoptosis (Qin et al. 1994; Shan and Lee 1994; Wu and Levine 1994; Kowalik et al. 1995; Asano et al. 1996; Du et al. 1996). This property is not seen with all E2F genes but appears to be a property of specific E2Fs. In contrast with E2F-1, the overexpression of E2F-2 and E2F-3 failed to induce apoptosis even though they induced the expression of E2F target genes and drove cells into S phase (DeGregori et al. 1997). Exactly how E2F-1 induces apoptosis is not known. In many cells the bulk of E2F-1-induced apoptosis appears to be p53-dependent (Qin et al. 1994; Wu and Levine 1994; Kowalik et al. 1995) and is associated with an increase in p53 levels (Hiebert et al. 1995). It is uncl ear whether the increase in p53 levels is caused by the proposed physical interaction between E2F-1 with M DM-2 (Martin et al. 1995), or that between DP-1 and p53 (O 'C onnor et al . 1995; Sorensen et al. 1996), or by another mechanism.

Recent reports suggest that p19ARF, a protein that stabilizes p53 and activates p53-dependent transcription (Pomerantz et al. 1998; Zhang et al. 1998), provides an important connection between E2F-1 and p53. p19ARF expression can be induced by E2F-1 (DeGregori et al. 1997), and its expression is slightly elevated in $\mathrm{Rb}^{-1-}$ cells (de Stanchina et al. 1998). Intriguingly p19ARF-deficient cells are partially resistant to E1A- or E2F-1-induced apoptosis (de Stanchina et al. 1998; Zindy et al. 1998).

Other studies have demonstrated that the overexpression of E2F-1 can induce apoptosis in cells that lack p53 (Hsieh et al. 1997; Phillips et al. 1997), indicating that there must be a least two mechanisms for E2F-induced apoptosis. M apping experiments reveal ed that the DN Abinding domain of E2F-1 was required for it to induce p53-independent apoptosis but an intact transactivation domain was not necessary.

Regulation of apoptosis is not simply an artifact of protein overexpression but it is likely to be an important aspect of E2F-1 function. Defects in apoptosis have been identified in thymocytes of E2F1 ${ }^{-1-}$ mice (Field et al. 1996) and inhibition of E2F activity has been reported to prevent apoptosi s in cultured cells (Bargou et al. 1996). In contrast, some studies have also reported that the inactivation of E2F can lead also to apoptosis (Bandara et al. 1997; Brook et al. 1996) but the basis for these effects is unclear. It is noteworthy that pRB-deficient embryos, in which E2F-1 is predicted to be deregulated, also show very high levels of apoptosis (Clarke et al. 1992; Jacks et al. 1992; Lee et al. 1992; Lee et al. 1994). Comparisons

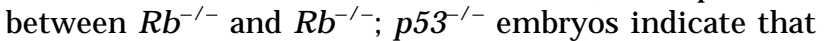
apoptosis caused by the absence of pRB is p53 dependent in the central nervous system (CN S) and the eye lens but p53 independent in the peripheral nervous system (PN S) (M orgenbesser et al. 1994; M acleod et al. 1996). It will be extremely interesting to know how much of these effects result from the deregulation of E2F-1.

The current data is consistent with the view that the levels of E2F are important for cell survival; in a general sense either too much or too little E2F activity may lead to apoptosis. Because of the damage that inappropriate cell proliferation can cause it makes a great deal of sense that elevated E2F activity should make cells prone to apoptosis. A similar coupling of proliferative and apoptotic signal s has previously been described for c-myc (for review, see Harrington et al. 1994). In the case of myc, specific survival factors are required to allow myc-driven cells to proliferate, and the same may be true for E2F-1. Conceptually this may provide a safeguard against constitutive signals to proliferate. Small DNA tumor viruses that depend on the host cell to replicate their genome appear to have solved this problem by encoding complementary sets of proteins that drive proliferation and inhibit apoptosis.

\section{How much do we really know?}

The experiments described above provide us with detailed information about the potential functions and activities of E2F. Much is known about the different types of E2F complexes, about the many ways in which E2F activities can be regulated, and about potential E2F-regulated genes. The general view of $\mathrm{E} 2 \mathrm{~F}$ as a factor that drives cell proliferation is supported by a weal th of data showing that E2F overexpression drives cells into $S$ phase.

However, recent analysis of animals lacking specific E2Fs have given surprising results that underscore the limitations of a knowledge that is derived mostly from bi ochemical studies of tissue culture cells. The inactivation of E2F is expected to inhibit cell proliferation, yet E2F-1-deficient mice are viable and fertile (Field et al. 1996; Yamasaki et al. 1996). These mice show defects in apoptosis and, contrary to most predictions, are tumorprone. No defects in cell proliferation were apparent in E2F-5-deficient animals (Lindeman et al. 1998). Instead these mice develop hydrocephalus caused by excessive secretion of cerebrospinal fluid. It is unclear how to explain these phenotypes using the current molecular models for E2F action. Are the developmental defects due to very specific roles for individual E2Fs in cell pro- 
liferation? Are our models wrong and do these phenotypes reflect new functions for E2Fs?

Interpretation of the knockout phenotypes is difficult because so little is known about the extent of functional overlap between E2F family members or the degree of compensation that occurs in knockout cells. Fewer E2F and DP family members have been found in Drosophila but studies of E2F mutations in flies have also given unexpected results. dE2F and dDP mutant animals continue to develop until relatively late stages (Royzman et al. 1997; Duronio et al . 1998). These embryos lack a program of gene expression that normally accompanies the $\mathrm{G}_{1}$ - to S-phase transition, but DN A synthesi s still occurs and, at least in dDP mutants, appears to be relatively normal. Does this mean that E2F-dependent transcription is relatively unimportant for DNA synthesis or are there additional family members in Drosophila that carry out the essential functions?

In addition to the questions posed by in vivo studies, the size of the E2F literature hides the fact that several fundamental issues remain unresolved. To illustrate some of these issues, I have picked five questions that have been highlighted in recent publications. The ideas and results behind these questions are described below.

\section{Is E2F required for S-phase entry?}

As el evated E2F activity can drive cells into $S$ phase and the overexpression of pRB can block cells in $G_{1}$, it has been widely assumed that the activation of E2F-dependent transcription is essential for cells to enter $\mathrm{S}$ phase. Although this sounds like it ought to be a straightforward point to test, in fact the issue of whether activation of E2F is required for $S$ phase is still not settled. One approach to this question is to examine the effects of inactivating E2F. This has been problematic because of the large number of genes encoding E2F and DP proteins and because of the difficulties involved in proving that E2F is completely and specifically inactivated. Exactly how much E2F-dependent transcription is functionally significant remains a contentious issue. For example, if the expression of E2F target genes is reduced to $10 \%$, is this sufficient activity for S-phase entry? The analysis of mice or flies carrying mutations in multiple E2F or DP family members may resolve this issue. However, the complete inhibition of E2F binding may actually derepress promoters that are controlled by E2F-repressor complexes, and it is not clear that the analysis of a completely E2F-deficient mutant will provide an unambiguous answer.

There is compelling evidence that E2F activity is ratelimiting for S-phase entry. $\mathrm{N}$ ot only does elevated E2F activity drive cells into $S$ phase, but inhibitors of E2F reduce S-phase entry. The proportion of cells in $G_{1}$ is increased by the overexpression of dominant-negative mutants of E2F-1, DP-1 and DP-2 (Dobrowolski et al. 1994; Wu et al. 1996; Fan and Bertino 1997) or by the expression of competitor RN A molecules (Ishizaki et al. 1996). Similarly, the expression of a transcriptional repressor fused to the DNA-binding domain of E2F-1 causes an accumulation of $\mathrm{G}_{1}$-phase cells (Sellers et al. 1995). Microinjection of antibodies to E2F-3 reduced the percentage of REF52 cells entering S phase (Leone et al. 1998). Consistent with these observations, DN A synthesis is sharply reduced in dE2F mutants (Duronio et al. 1995), suggesting that E2F-dependent transcription is rate limiting for cell cycle progression in vivo.

However, S-phase entry is not completely eliminated in any of these experimental settings. Indeed, clones of dE2F mutant cells can be found (Brook et al. 1996) and both the dE2F and dDP homozygous mutants continue to support DN A synthesis (Royzman et al. 1997). These animals show continued development in the absence of detectable expression of RNR2 and PCNA, two proposed E2F-target genes. In tissue culture cells, recent studies have used mutant forms of pRB that lack cdk phosphorylation sites and are thought to be constitutive inhibitors of E2F, to impose a cell cycle block. Surprisingly, this arrest is overcome by the overexpression of cyclin $E$ (Lukas et al. 1997). These cyclin E-induced S phases result in a complete doubling of DNA content and occur without overt activation of E2F-dependent transcription (Leng et al. 1997; Lukas et al. 1997). In a similar way, expression of cyclin $\mathrm{E}$ can bypass a cell cycle arrest caused by $\mathrm{p} 16^{\mathrm{INK} 4 \mathrm{a}}$ without apparently stimulating pRB phosphorylation (Alevizopoulos et al. 1997) and can overcome the cell cycle effects of a dominant-negative DP-1 mutant (Lukas et al. 1997).

Such results can be interpreted in several different ways and it is not clear which explanation is correct. One interpretation is that E2F-dependent transcription is absolutely required for DNA synthesis and that a Iow (and undetected) level of E2F activity remains in each of these experimental conditions. A second interpretation is that E2F facilitates DNA synthesis but is not absolutely required for each cell cycle. Because E2F has many target genes, one could imagine that the program of E2Fdependent transcription is required for cells to move from a quiescent state to a proliferative state that can support DNA synthesis. Once cells are actively proliferating, a new burst of E2F activity may not be absolutely necessary to initiate DNA synthesis. A third interpretation of these experiments is that one of the key functions of E2F is to promote expressi on of cyclin $E$ (see bel ow). In this case ectopic expression of cyclin E could transiently bypass a need for E2F until other E2F targets become limiting. For this scenario, one has to argue that in Drosophila the expression of cyclin $\mathrm{E}$ can be induced independently of dDP or dE2F and that there is a low level of cyclin $\mathrm{E}$ expression in dDP or dE2F mutants that can support DNA replication. There is evidence for both of these points (Duronio and O'Farrell 1995; Royzman et al. 1997; Duronio et al. 1998).

\section{What are the key targets of E2F activity?}

A critical step toward understanding the action of E2F is the identification of the important targets that connect E2F activation to cell cycle progression, to the initiation of DNA synthesis, or to the induction of apoptosis. 
There are many candidates for the first two activities. Genes that are responsive to E2F include well-studied cell cycle regulators including cyclin E, cyclin A, cdc2, and cdk2 (Dalton 1992; Furukawa et al. 1994; Ohtani et al. 1995; Tommasi and Pfeifer 1995; Schulze et al. 1995; Botz et al . 1996; Geng et al. 1996; Huet et al . 1996). Other E2F target genes include those that encode functions that are important for DNA synthesis, such as DNA polymerase $\alpha$ (Pearson et al. 1991), thymidine kinase (Ogris et al. 1993; Karlseder et al. 1996), and DHFR (for review, see Slansky and Farnham 1996). M ore di rect connections to DNA replication may be provided by the discovery that the expression of orcl (Ohtani et al. 1996), cdc6 (Yan et al. 1998), and multiple MCM genes (Duronio et al. 1998; Leone et al. 1998) can also be induced by E2F. These and other E2F target genes are reviewed in Helin (1998) and Sardet et al. (1997). A simple explanation for E2F-induced apoptosis is that E2F-1 specifically regulates the expression of a gene(s) that promotes apoptosis. In mammalian cells, the best candidate for such a target is p19ARF (DeGregori et al. 1997; de Stanchina et al. 1998; Zindy et al. 1998). In Drosophila, dE2F-induced apoptosis is preceded by el evated levels of reaper (Asano et al. 1996); however, it is unclear whether this is a di rect or an indirect effect of dE2F.

The plethora of potential E2F target genes raises the basic question of whether a single E2F target is rate limiting for DNA synthesis or cell cycle progression, or whether E2F stimulates DNA synthesis by coordinately inducing the expression of many genes. The critical test is to determine whether el evated expression of any one of these targets could substitute for the activation of E2F. Potentially, the rate-limiting component could vary in different cells and in different situations. To date the only E2F-regulated gene shown to be capable of repl acing E2F is cyclin E. The decline in DNA synthesis in dE2F mutant embryos can be rescued transiently by ectopic expression of cyclin E (Duronio and O'Farrell 1995), strongly suggesting that cyclin $E$ is a rate-limiting target. Whether cyclin E is the only E2F target gene that is capable of doing this is unclear.

However, attempts to place cyclin $E$ and $d E 2 F$ in a linear pathway have led to conflicting results. Different experiments suggest that either cyclin E or E2F can be placed upstream of the other in different situations. E2F can induce expression of cyclin E (Ohtani et al. 1995; Botz et al. 1996; Geng et al. 1996) suggesting that cyclin $\mathrm{E}$ acts downstream of E2F. In addition, cyclin E-dependent kinases can phosphorylate pRB-family proteins (Hinds et al. 1992), potentially allowing cyclin $E$ to act upstream of E2F. It is often proposed that cyclin $E$ and E2F comprise a feed-forward loop all owing ampl ification of signals that promote the $\mathrm{G}_{1}$ - to S-phase progression.

Studies in Drosophila suggest that the epistasis of cyclin $\mathrm{E}$ and $\mathrm{dE} 2 \mathrm{~F}$ varies between cell types (Duronio and O'Farrell 1995), perhaps influenced by the variable importance of E2F in determining cycl in E expression compared to other transcri ption factors. In mammalian cells, the overexpression of cyclin $E$ has been found to drive cells into $\mathrm{S}$ phase in the absence of measurable E2F ac- tivity (Lukas et al . 1997), but conversely, the overexpression of E2F-1 was found to drive cells into S phase without significant activation of cyclin E-associated kinases (DeGregori et al. 1995). A way to reconcile these apparently contradictory observations is suggested by $\mathrm{N}$ evins and colleagues who proposed that the functions of E2F and cyclin E may converge in the product of an E2Ftarget gene(s) that acts at the initiation of DN A synthesis in a process that is modulated by cyclin E-dependent phosphorylation (J.R. Nevins, pers. comm.). In this model, overexpression of the target may minimize the need for cdk phosphorylation whereas elevated phosphorylation may enable lower levels of the protein to be sufficient for activity. The identity of such a target is not known. One potential candidate is CDC6, as CDC6 is an unstable protein that is important in the initiation of DN A synthesis (Kelly et al. 1993; Piatti et al. 1995) and whose promoter is regulated by E2F-binding sites (Williams et al. 1997; Leone et al 1998; Yan et al. 1998). Experiments in Drosophila suggest that cycl in E and E2F have independent targets in addition to any common targets. This is implied by experiments showing that dE2F/ dDP expression was unable to rescue DN A synthesis in cyclin Emutant embryos (Duronio et al. 1996), and that the rescue of DNA synthesis in dE2F-mutant embryos by cyclin E was very short-lived (Duronio and O'Farrell 1995).

Although most E2F target genes provide links to DN A synthesis and cell cycle progression, many of these promoters were chosen for study for this very reason. The full spectrum of E2F target genes remains to be determined. E2F expression persists in quiescent and differentiated cells. The analysis of dE2F-mutant clones (Brook et al. 1996) and E2F-5 knockout mice (Lindeman et al. 1998) suggests that E2F has important functions in cells that are not actively proliferating. One interesting possibility is that these functions may reflect a role for E2F repressor compl exes. As the functions of E2F in postmitotic cells are al most completely unexplored it is unclear whether the critical targets of E2F are the same in proliferating and differentiated cells.

\section{What is the role of PRB in E2F regulation?}

E2F activity is the sum of many different parts and, despite their publicity, pRB/E2F complexes represent only a minor fraction of the total E2F complexes present in cell extracts. As more details have emerged about the number of different E2F complexes and the tiers of E2F regulation, it has become increasingly evident that the absence of pRB does not completely deregulate E2F. To understand the role of $\mathrm{pRB} / \mathrm{E} 2 \mathrm{~F}$ complexes we need to discover exactly which aspects of E2F regulation are provided by $\mathrm{pRB}$.

This issue is not readily investigated by protein overexpression. Although pRB is a potent inhibitor of E2F when expressed at high levels, overexpressed pRB-family members bind to a broader range of E2Fs than the endogenous proteins. It is uncertain whether the effects caused by high levels of pRB genuinely represent the normal 
functions of this protein. Because of this, recent attempts to separate the individual functions of pRB, p107, and 130 have focused on the changes seen in cultures of primary mouse cells lacking specific family members.

$\mathrm{Rb}^{-1-}$ mouse embryo fibroblasts (MEFs) have a slightly shorter $G_{1}$ phase and enter $S$ phase $\sim 2 \mathrm{hr}$ earlier than wild-type cells (Herrera et al. 1996). In synchronized $\mathrm{Rb}^{-1-}$ cells, most E2F target genes are induced at their normal time relative to S-phase entry. However two genes, cyclin E and p107 are expressed earlier than normal and their products accumulate to higher levels (Herrera et al. 1996; Hurford et al. 1997). In contrast, no dif-

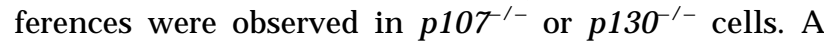
different set of genes were deregulated in $\mathrm{plO}^{-1}$; p130-1- cells illustrating that p107 and p130 have overlapping functions and that pRB and p107/p130 are required for the normal expression of different subsets of E2F targets (Hurford et al. 1997).

These experiments indicate that pRB-family members have different functions in E2F regulation. It is possible that these differences in E2F regulation underlie the different biological properties of the pRB-family members but this idea is still largely untested. The full spectrum of changes in the expression of E2F-target genes in $\mathrm{Rb}^{-1-}$ cells has yet to be determined. N ew targets for E2F continue to be found and there is no guarantee that the first changes found will be the most important.

Although the changes seen in $\mathrm{Rb}^{-1-}$ cells may reflect the changes in E2F-dependent transcription that occur during tumorigenesis, such studies likely underestimate the actual role of $\mathrm{pRB}$ in $\mathrm{E} 2 \mathrm{~F}$ regulation. In the absence of $\mathrm{pRB}$, many of its functions may be carried out by p107 or p130. The analysis of $\mathrm{Rb}^{-1} ; \mathrm{plO7}^{-1}$, and $\mathrm{plO7}^{-1-}$; $\mathrm{p} 130^{-1-}$ mice suggest that there is extensive functional overlap between pRB-family members (Cobrinik et al.

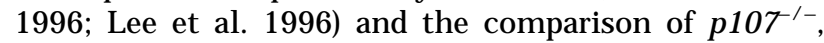

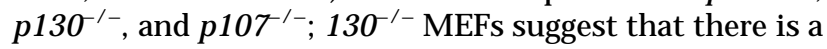
similar degree of overlap in E2F regulation. At present it is unclear whether this is because the pRB-family proteins have functions that are largely redundant or whether family members compensate for one another in knockout cells. If it is possible to identify the individual E2F complexes bound at the endogenous promoters then these issues may be resolved.

The changes in E2F-dependent transcription that occur when $\mathrm{pRB}$ is removed may be very different in different cell types. The pattern of E2F-target genes misexpressed in p107 ${ }^{-1-}$; p130 $30^{-1-}$ cells and the ability of pRBfamily members to compensate for one another differs slightly between cultures of MEFs and T cells (Hurford et al. 1997; Mulligan et al. 1998). For example, pRB/E2F complexes clearly increase in $\mathrm{p} 30^{-1-} \mathrm{T}$ cells, whereas this increase is not readily evident in $\mathrm{p}^{130^{-1-}}$ MEFs (Mulligan et al. 1998). An added level of complexity is suggested by the work of M. Rudnicki and coworkers who have observed that the phenotype of mice lacking pRB-family members varies dramatically in different genetic backgrounds (M. Rudnicki, J.E. LeCouter, B. Kabler, W.R. Hardy, C. Ying, L.A. Megeney, L.L. Max, and M.A. Rudnicki, pers. comm.). Such strain differences will provide important insights into the functional relationships between pRB-family members and highlight the fact that there is not a single answer to these questions.

\section{Is the ability of pRB to bind E2F important for pRB's role as a tumor suppressor?}

One of the most appealing aspects of the pRB/E2F interaction was the prospect that this complex could explain the growth suppressor properties and perhaps the tumor suppressor properties of pRB. By now however, 50 different polypeptides have been reported to physically interact with pRB (e.g., see Mulligan and Jacks 1998); of these, only six are components of E2F (E2F-1, E2F-2, E2F3, E2F-4, DP-1, DP-2). Although the evidence for many of these interactions is less extensive than for E2F, the steady increase in the number and diversity of pRB-associated proteins has continued to emphasize an important gap in our knowledge. Despite the fact that E2F and pRB have antagonistic activities when they are overexpressed it is still not clear what fraction of pRB's functions are attributable to its regulation of E2F.

Ideally, we would like to study the properties of a pRB mutant that fails to bind to E2F but retains all other activities. However, many of the pRB-binding proteins interact with similar regions of $\mathrm{pRB}$ and the commonly used tumor-derived mutant alleles encode proteins that fail to interact with multiple pRB-binding proteins. To date no pRB mutation has been characterized in sufficient detail to show that it specifically eliminates E2Fbinding but leaves other interactions intact. In contrast, several studies have shown that E2F binding is not sufficient for the growth suppression properties of pRB (Qian et al. 1992; Zhu et al . 1993; Welch and Wang 1995; Sellers 1998). Recent analysis of two partially penetrant, mutant alleles of human RB showed that these encode proteins that fail to bind to E2F and are unable to repress E2F-dependent transcription but these retain other pRB activities (Sellers 1998). This result indicates that the difference between partially penetrant and fully penetrant $\mathrm{Rb}$ mutations can be separated from E2F regulation. Such studies illustrate that E2F-regulation is only one aspect of $\mathrm{pRB}$ function and emphasize the need to identify other pRB-binding proteins that are important for tumor suppression.

An alternative approach to this issue is to ask whether E2F mutations that liberate the endogenous E2F proteins from $\mathrm{pRB}$ are sufficient for tumor formation. Both wildtype and mutant E2F genes score in transformation assays (Johnson et al. 1994a) and drive cells into S phase when overexpressed in tissue culture cells (Shan et al. 1996). It will be extremely interesting to know whether anal ogous mutations in endogenous proteins can achieve a similar effect.

If pRB were to act simply by restraining the activity of E2F then the amplification of E2F genes might be expected to occur frequently in tumors as an alternative to pRB mutation. Despite extensive searches only a single cell line has been reported to show amplification of the 
E2F1 locus (Saito et al. 1995). Perhaps the most direct evidence to suggest that E2F-regulation is relevant for tumor suppression by $\mathrm{pRB}$ is the finding that the pituitary and thyroid tumor phenotypes of $\mathrm{Rb}^{+/-}$mice are reduced and delayed in animals deficient for E2F-1 (Yamasaki et al. 1998). Although E2F-1 is not required for the proliferation of $\mathrm{Rb}^{-1-}$ tumor cells, this result suggests that the liberation of E2F-1 contributes significantly to the development of $\mathrm{Rb}^{-1-}$ tumors. Similarly, in transgenic models, the absence of E2F-1 severely reduces the inappropriate cell proliferation caused by viral oncoproteins (HPV-16 E7 or a fragment of SV40 large T antigen) that bind to pRB, p107, and p130 (J. McCaffrey, L. Yamasaki, N. Dyson, E. Harlow, and A.E. Griep; H. Pan, C. Yin, N. Dyson, E. Harlow, L Yamasaki, and T. Van Dyke; both in prep). Thus, while E2F may not betheonly target of $\mathrm{pRB}$, the deregulation of E2F-1 does appear to be important for the proliferation of cells lacking functional pRB-family proteins. As E2F-1 is not required for most aspects of mouse development it is possible that specific inhibitors of E2F-1 might provide therapeutics for some pRB-minus tumors. However, the discovery that E2F- 1 is a tumor suppressor gene in mice rai ses serious concerns about intervention strategies that are based on the inactivation of $\mathrm{E} 2 \mathrm{~F}$.

\section{How can E2F-1 be both an oncogene and a tumor suppressor gene?}

E2F-1 presents us with a wonderful paradox. On one hand, E2F-1 behaves as a standard oncogene in transformation assays (Johnson et al . 1994a; Singh et al. 1994; Xu et al. 1995), the overexpression of E2F-1 in transgenic mice promotes tumorigenesis (Pierce et al. 1998), and the absence of E2F-1 reduces tumor phenotypes resulting from the inactivation of pRB (Yamasaki et al. 1998). Thus E2F-1 has many of the properties of a bonafide oncogene and appears to promote tumor cell proliferation. On the other hand, E2F-1 knockout mice devel op a broad spectrum of tumors including tumors of the reproductive tract, lymphomas, and lung adenocarcinomas ( $\mathrm{Ya}$ masaki et al. 1996). As defined by this functional assay, E2F-1 is a tumor suppressor gene.

How does one explain such different roles for E2F? As the overexpression of E2F genes can promote cell cycle progression it is easy to imagine how E2F-1 can act as an oncogene. However the reasons why E2F-1 is a tumor suppressor are less clear. One model suggests that the dual nature of E2F-1 is a consequence of the fact that E2F-binding sites can mediate both the activation and repression of its target genes. In this model, E2F-1 mediates some of the tumor suppressor activities of $p R B$ by recruiting it to DNA and allowing $\mathrm{pRB}$ to repress the expression of a set of critical genes. Differences in the tumor spectrum of $\mathrm{E} 2 \mathrm{~F}^{-1-}$ and $\mathrm{Rb}^{+1-}$ animals might be explained by the overlapping functions of E2F genes in many cell types. If this model is true then there are some clear predictions. For example, point mutations in E2F-1 that eliminate pRB binding should give a tumor phenotype similar to that caused by E2F-1 null mutations. Fur- thermore, if this model is true then mice lacking other pRB-regulated E2Fs (E2F-2, E2F-3, and E2F-4) might al so be expected to develop tumors for the same reason.

A second explanation for the tumor suppressor activity of E2F-1 stems from the observation of E2F-1-induced apoptosis. If deregulated E2F-1 induces apoptosis in premalignant cells then the inactivation of E2F-1 may promote tumorigenesis by allowing the survival of inappropriately proliferating cells. This model emphasizes the fact that the net effects of deregulated E2F activity will depend on the relative levels of E2F-induced proliferation and E2F-induced apoptosis. If this model is correct then E2F-1 might bethe only member of the mammalian E2F gene family to be a tumor suppressor, as only E2F-1 has been shown to cause high levels of apoptosis. This model can be tested in vivo using mutations that specifically eliminate the apoptotic activity of E2F-1.

Although these are the models that are discussed most frequently many other models are also possible. Conceivably, the tumor phenotype of E2F-1-deficient animals may be due to a non-cell autonomous function of E2F-1 or by an alteration in the immune system (Weinberg 1996). Perhaps the tumor phenotype reflects a role for E2F in repair of DNA damage or is due to the overcompensation by other E2F-family members. Clearly a more detailed anal ysis is needed. It seems likely that the role of E2F-1 in tumorigenesis will vary considerably depending on cell type. Strikingly, within a single $\mathrm{Rb}^{+1-}$; $\mathrm{E} 2 \mathrm{~F}^{-1-}$ animal the absence of E2F-1 can promote tumorigenesis in some tissues while simultaneousl y del aying the development of $\mathrm{Rb}^{-1-}$ tumors in others ( $\mathrm{Y}$ amasaki et al. 1998).

\section{Perspective}

Biochemical and functional studies of E2F show that it is a multifaceted factor. E2F has the ability to mediate transcriptional activation or repression of target genes, to promote cell proliferation or apoptosis, and to promote or inhibit tumorigenesis in a tissue-specific manner. Such a range of functions is remarkable and provides a fascinating problem. A critical goal of future studies is to provide molecular explanations for these different biological effects. This will require a comprehensive understanding of the activities of individual E2Fs and knowledge of their specific targets. Clearly, there is no single activity or interaction that is responsible for all the of the properties of E2F. In vivo studies of these proteins tell us that the role of E2F- and pRB-family proteins will vary depending on whether the cells are proliferating or differentiating, and depending on the specific cell type.

The interaction between pRB and E2F needs to be placed carefully into context. E2F activity is controlled in multiple ways and pRB-association provides only one element, perhaps a relatively small el ement, of the regulatory process. The converse may also be true. E2F is only one of many proteins that have been reported to interact with pRB. While the bi ology of E2F suggests that it should be a critical target, it will be important to discover precisely how much of pRB's developmental or 
tumor suppressor activities are due to its interaction with E2F.

\section{Acknowledgments}

My sincere thanks go to Dan Haber, Ed Harlow, Iswar Hariharan, Tyler Jacks, M arie Classon, Brian Kennedy, Fred Dick, and Simon Boulton for wading through various drafts of this manuscript. Their helpful comments and suggestions were invaluable. I am grateful to Terry Van Dyke, Bruce Edgar, Stefan Gaubatz, Anne Griep, Kristian Helin, David Huen, David Johnson, Jackie Lees, David Livingston, Joe $\mathrm{N}$ evins, and $\mathrm{Mi}$ chael Rudnicki for their permission to cite work prior to publication. It was impossible to mention everything, and I apologize to colleagues for the many papers that there just was not room to include. This work was supported by $\mathrm{N}$ ational Institutes of Health grants CA 64402 and GM 53203.

\section{References}

Adnane, J., Z. Shao, and P.D. Robbins. 1995. The retinoblastoma susceptibility gene product represses transcription when directly bound to the promoter. J. Biol. Chem. 270: 8837-8843.

Alevizopoulos, A., J. Vlach, S. Hennecke, and B. Amati. 1997. Cyclin E and C-Myc promote cell proliferation in the presence of $\mathrm{p} 16^{\mathrm{IN} \mathrm{K4a}}$ and of hypophosphorylated retinoblastoma family proteins. EMBO J. 16: 5322-5333.

Altiok, S., M. Xu, and B.M. Spiegelman. 1997. PPAR $y$ induces cell cycle withdrawal: Inhibition of E2F/DP DNA-binding activity via down-regulation of PP2A. Genes \& Dev. 11: 1987-1998.

Asano, M., J.R. Nevins, and R.P. Wharton. 1996. Ectopic E2F expression induces $S$ phase and apoptosis in Drosophila imaginal discs. Genes \& Dev. 10: 1422-1432.

Bagchi, S., P. Raychaudhuri, and J. N evins. 1990. Adenovirus E1A proteins can dissociate heteromeric complexes involving the E2F transcription factor: A novel mechanism for E1A trans-activation. Cell 62: 659-669.

Bagchi, S., R. Weinmann, and P. Raychaudhuri. 1991. The retinoblastoma protein copurifies with E2F-I, an E1A-regulated inhibitor of the transcription factor E2F. Cell 65: 1063-1072.

Bandara, L.R. and N.B. La Thangue. 1991. Adenovirus E1A prevents the retinoblastoma gene product from complexing with a cellular transcription factor. Nature 351: 494-497.

Bandara, L.R., V.M. Buck, M. Zamanian, L.H. Johnston, and N.B. La Thangue. 1993. Functional synergy between DP-1 and $\mathrm{E} 2 \mathrm{~F}-1$ in the cell cycle-regulating transcription factor DRTF1/E2F. EMBO J. 12: 4317-4324.

Bandara, L.R., R. Girling, and N.B. La Thangue. 1997. A poptosis induced in mammalian cells by small peptides that functionally antagonize the Rb-regulated E2F transcription factor. Nature Biotech. 15: 896-901.

Bargou, R.C., C. Wagener, K. Bommert, W. Arnold, P.T. Daniel, M.Y. Mapara, E. Grinstein, H.D. Royer, and B. Dorken. 1996. Blocking of transcription factor E2F/DP by dominant-negative mutants in a normal breast epithelial cell line efficiently inhibits apoptosis and induces tumor growth in SCID mice. J. Exp. Med. 183: 3-10.

Beijersbergen, R.L., R.M. Kerkhoven, L. Zhu, L. Carlee, P.M. Voorhoeve, and R. Bernards. 1994. E2F-4, a new member of the E2F gene family, has oncogenic activity and associates with p107 in vivo. Genes \& Dev. 8: 2680-2690.

Beijersbergen, R.L., L. Carlee, R.M. Kerkhoven, and R. Bernards. 1995. Regulation of the retinoblastoma protein-related p107 by $\mathrm{G}_{1}$ cyclin complexes. Genes \& Dev. 9: 1340-1353.
Botz, J., K. Zerfass-Thome, D. Spitkovsky, H. Delius, B. Vogt, M. Eilers, A. Hatzigeorgiou, and P. Jansen-Dürr. 1996. Cell cycle regulation of the murine cyclin $\mathrm{E}$ gene depends on an E2F binding site in the promoter. Mol. Cell. Biol. 16: 34013409.

Brehm, A., E.A. Miska, D.J. McCance, J.L. Reid, A.J. Bannister, and T. Kouzarides. 1998. Retinoblastoma protein recruits histone deacetylase to repress transcription. Nature 391: 597-601.

Bremner, R., B.L. Cohen, M. Sopta, P.A. Hamel, C.J. Ingles, B.L. Gallie, and R.A. Phillips. 1995. Direct transcriptional repression by pRB and its reversal by specific cyclins. Mol. Cell. Biol. 15: 3256-3265.

Brook, A., J.-E. Xie, W. Du, and N. Dyson. 1996. Requirements for $\mathrm{dE} 2 \mathrm{~F}$ function in proliferating cells and in post-mitotic differentiating cells. EMBO J. 15: 3676-3683.

Cao, L., B. Faha, M. Dembski, L.-H. Tsai, E. Harlow, and N. Dyson. 1992. Independent binding of the retinoblastoma protein and p107 to the transcription factor E2F. Nature 355: 176-179.

Cartwright, P., H. Müller, C. Wagener, K. Holm, and K. Helin. 1998. E2F-6: A novel member of the E2F family is an inhibitor of E2F-dependent transcription. Oncogene 16: (in press).

Chellappan, S., S. Hiebert, M. M udryj, J. Horowitz, and J. N evins. 1991. The E2F transcription factor is a cellular target for the RB protein. Cell 65: 1053-1061.

Chittenden, T., D. Livingston, and W. Kaelin. 1991. The T/E1Abinding domain of the retinoblastoma product can interact selectively with a sequence-specific DNA-binding protein. Cell 65: 1073-1082.

Chittenden, T., D.M. Livingston, and J.A. DeCaprio. 1993. Cell cycle analysis of E2F in primary human $T$ cells reveals novel E2F complexes and biochemically distinct forms of free E2F. Mol. Cell. Biol. 13: 3975-3983.

Clarke, A., E. M aandag, M. van Roon, N. van der Lugt, M. van der Valk, M. Hooper, A. Berns, and H. te Riele. 1992. Requirement for a functional $\mathrm{Rb}-1$ gene in murine development. Nature 359: 328-330.

Cobrinik, D., P. Whyte, D.S. Peeper, T. Jacks, and R.A. Weinberg. 1993. Cell cycle-specific association of E2F with the p130 E1A-binding domain. Genes \& Dev. 7: 2392-2404.

Cobrinik, D., M.-H. Lee, G. Hannon, G. Mulligan, R.T. Bronson, N. Dyson, E. Harlow, D. Beach, R.A. Weinberg, and T. Jacks. 1996. Shared role of the pRB-related p130 and p107 proteins in limb development. Genes \& Dev. 10: 1633-1644.

Cress, W.D. and J.R. N evins. 1996. A role for a bent DN A structure in E2F-mediated transcription activation. Mol. Cell. Biol. 16: 2119-2127.

Dagnino, L., C. Fry, S. Bartley, P. Farnham, B. Gallie, and R.A. Phillips. 1997a. Expression of E2F transcription factors during mouse nervous system devel opment. Mech. Dev. 66: 1325.

- - - 1997b. Expression patterns of the E2F family of transcription factors during murine epithelial development. Cell Growth \& Differ. 8: 553-563.

Dalton, S. 1992. Cell cycle regulation of the human cdc2 gene. EMBO J. 11: 1797-1804.

Datta, P.K., P. Raychaudhuri, and S. Bagchi. 1995. Association of p107 with Spl: Genetically separable regions of p107 are involved in regulation of E2F- and Spl-dependent transcription. Mol. Cell. Biol. 15: 5444-5452.

DeGregori, J., T. Kowalik, and J. N evins. 1995a. Cellular targets for activation by the E2F1 transcription factor include DNA synthesis- and G1/S-regulatory genes. Mol. Cell. Biol. 15: 4215-4224.

DeGregori, J., G. Leone, A. Miron, L. Jakoi, and J.R. Nevins. 
1997. Distinct roles for E2F proteins in cell growth control and apoptosis. Proc. Natl. Acad. Sci. 94: 7245-7250.

DeGregori, J., G. Leone, K. Ohtani, A. Miron, and J.R. N evins. 1995b. E2F-1 accumulation bypasses a $G_{1}$ arrest resulting from the inhibition of $\mathrm{G}_{1}$ cyclin-dependent kinase activity. Genes \& Dev. 9: 2873-2887.

de la Luna, S., M.J. Burden, C.-W. Lee, and N.B. La Thangue. 1996. N uclear accumulation of the E2F heterodimer regulated by subunit composition and alternative splicing of a nuclear localization signal. J. Cell Sci. 109: 2443-2452.

de Stanchina, E., M.E. McCurrach, F. Zindy, S.-Y. Shieh, G. Ferbeyre, A.V. Samuelson, C. Prives, M.F. Roussel, C.J. Sherr, and S.W. Lowe. 1998. E1A signaling to p53 involves the p19ARF tumor suppressor. Genes \& Dev. (this issue).

Devoto, S.H., M. Mudryj, J. Pines, T. Hunter, and J.R. N evins. 1992. A cyclin A-protein kinase complex possesses se quence-specific DNA binding activity: $p 33^{\text {cdk2 }}$ is a component of the E2F-cyclin A complex. Cell 68: 167-176.

Dobrowolski, S.F., D.W. Stacey, M.L. Harter, J.T. Stine, and S.W. Hiebert. 1994. An E2F dominant negative mutant blocks E1A induced cell cycle progression. Oncogene 9: 2605-2612.

Du, W., J.-E. Xie, and N. Dyson. 1996. Ectopic expression of $\mathrm{dE} 2 \mathrm{~F}$ and $\mathrm{dDP}$ induces cell proliferation and death in the Drosophila eye. EMBO J. 15: 3684-3692.

Dunaief, J.L., B.E. Strober, S. Guha, P.A. Khavari, K. Alin, J. Luban, M. Begemann, G.R. Crabtree, and S.P. Goff. 1994. The retinoblastoma protein and BRG 1 form a complex and cooperate to induce cell cycle arrest. Cell 79: 119-130.

Duronio, R.J. and P.H. O'Farrell. 1995. Developmental control of the $\mathrm{G}_{1}$ to $\mathrm{S}$ transition in Drosophila; cyclin $\mathrm{E}$ is a limiting downstream target of E2F. Genes \& Dev. 9: 1456-1468.

Duronio, R.J., P.H. O'Farrell, J.-E. Xie, A. Brook, and N. Dyson. 1995. The transcription factor E2F is required for $S$ phase during Drosophila embryogenesis. Genes \& Dev. 9: 14451455.

Duronio, R.J., A. Brook, N. Dyson, and P.H. O'Farrell. 1996. E2F-induced S phase requires cyclin E. Genes \& Dev. 10: 2505-2513.

Duronio, R.J., P.C. Bonnette, and P.H. O'Farrell. 1998. Mutations of the Drosophila dDP, dE2F, and cyclin E genes reveal distinct roles for the E2F-DP transcription factor and cyclin E during the S-phase transition. Mol. Cell. Biol. 18: 141-151.

Dynlacht, B.D., A. Brook, M.S. Dembski, L. Yenush, and N. Dyson. 1994a. DNA-binding and trans-activation properties of Drosophila E2F and DP proteins. Proc. Natl. Acad. Sci. 91: 6359-6363.

Dynlacht, B.D., O. Flores, J.A. Lees, and E. Harlow. 1994b. Differential regulation of E2F trans-activation by cyclin-cdk2 complexes. Genes \& Dev. 8: 1772-1786.

Emili, A. and C.J. Ingles. 1995. Promoter-dependent photocrosslinking of the acidic transcriptional activator E2F-1 to the TATA-binding protein. J. Biol. Chem. 270: 13674-13680.

Fagan, R., K.J. Flint, and N. Jones. 1994. Phosphorylation of E2F-1 modulates its interaction with the retinoblastoma gene product and the adenoviral E4 $19 \mathrm{kDa}$ protein. Cell 78: 799-811.

Fan, J. and J.R. Bertino. 1997. Functional roles of E2F in cell cycle regulation. Oncogene 14: 1191-1200.

Farnham, P.J., ed. 1995. Transcriptional control of cell growth: The E2F gene family. Curr. Top. Microbiol. Immunol. 208.

Fattaey, A.R., E. Harlow, and K. Helin. 1993. Independent re gions of adenovirus E1A are required for binding to and dissociation of E2F-protein complexes. Mol. Cell. Biol. 13: 7267-7277.

Field, S.J., F.-Y. Tsai, F. Kuo, A.M. Zubiaga, W.G. Kaelin, Jr.,
D.M. Livingston, S.H. Orkin, and M.E. Greenberg. 1996. E2F-1 functions in mice to promote apoptosis and suppress proliferation. Cell 85: 549-561.

Flemington, E.K., S.H. Speck, and W.G. Kaelin, Jr. 1993. E2F-1 mediated transactivation is inhibited by complex formation with the retinoblastoma susceptibility gene product. Proc. Natl. Acad. Sci. 90: 6914-6918.

Fry, C.J., J.E. Slansky, and P.J. Farnham. 1997. Position-dependent transcriptional regulation of the murine dihydrofolate reductase promoter by the E2F transactivation domain. Mol. Cell. Biol. 17: 1966-1976.

Furukawa, Y., Y. Terui, K. Sakoe, M. Ohta, and M. Saito. 1994. The role of cellular transcription factor $E 2 F$ in the regulation of cdc2 mRNA expression and cell cycle control of human hematopoietic cells. J. Biol. Chem. 269: 26249-26258.

Geng, Y., E.N . Eaton, M. Picon, J.M. Roberts, A.S. Lundberg, A. Gifford, C. Sardet, and R.A. Weinberg. 1996. Regulation of cyclin E transcription by E2Fs and retinoblastoma protein. Oncogene 12: 1173-1180.

Ginsberg, D., G. Vairo, T. Chittenden, Z.X. Xiao, G. Xu, K.L. Wydner, J.A. DeCaprio, J.B. Lawrence, and D.M. Livingston. 1994. E2F-4, a new member of the E2F transcription factor family, interacts with p107. Genes \& Dev. 8: 2665-2679.

Girling, R., J.F. Partridge, L.R. Bandara, N. Burden, N.F. Totty, J.J. Hsuan, and N.B. La Thangue. 1993. A new component of the transcription factor DRTF1/E2F. Nature 362: 83-87.

Girling, R., L.R. Bandara, E. Ormondroyd, E.W.-F. Lam, S. Kotecha, T. Mohun, and N.B. La Thangue. 1994. Molecular characterization of Xenopus laevis DP proteins. Mol. Biol. Cell 5: 1081-1092.

Guy, C.T., W. Zhou, S. Kaufman, and M.O. Robinson. 1996. E2F-1 blocks terminal differentiation and causes proliferation in transgenic megakaryocytes. Mol. Cell. Biol. 16: 685693.

Hagemeier, C., A. Cook, and T. Kouzarides. 1993. The retinoblastoma protein binds E2F residues required for activation in vivo and TBP binding in vitro. Nucleic Acids Res. 21: 4998-5004.

Hamel, P.A., R.M. Gill, R.A. Phillips, and B.L. Gallie. 1992. Transcriptional repression of the E2-containing promoters EllaE, c-myc, and RB1 by the product of the RBI gene. Mol. Cell. Biol. 12: 3431-3438.

Hao, X.F., L. Alphey, L.R. Bandara, E.W.-F. Lam, D. Glover, and N.B. La Thangue. 1995. Functional conservation of the cell cycle-regulating transcription factor DRTF1/E2F and its pathway of control in Drosophila melanogaster. J. Cell Sci. 108: 2945-2954.

Harrington, E.A., A. Fanidi, and G.I. Evan. 1994. Oncogenes and cell death. Curr. Opin. Genet. Dev. 4: 120-129.

Hateboer, G., R.M. Kerkhoven, A. Shvarts, R. Bernards, and R.L. Beijersbergen. 1996. Degradation of E2F by the ubiquitinproteasome pathway: Regulation by retinoblastoma family proteins and adenovirus transforming proteins. Genes \& Dev. 10: 2960-2970.

Helin, K. 1998. Regulation of cell proliferation by the E2F transcription factors. Curr. Opin. Genet. Dev. 8: 28-35.

Helin, K., J.A. Lees, M. Vidal, N. Dyson, E. Harlow, and A. Fattaey. 1992. A CDN A encoding a pRB-binding protein with properties of the transcription factor E2F. Cell 70: 337-350.

Helin, K., E. Harlow, and A.R. Fattaey. 1993a. Inhibition of E2F-1 transactivation by direct binding of the retinoblastoma protein. Mol. Cell. Biol. 13: 6501-6508.

Helin, K., C.-L. Wu, A. Fattaey, J. Lees, B. Dynlacht, C. N gwu, and $\mathrm{E}$. Harlow. 1993b. Heterodimerization of the transcription factors E2F-1 and DP-1 leads to cooperative transactivation. Genes \& Dev. 7: 1850-1861. 
Herrera, R.E., V.P. Sah, B.O. Williams, T.P. Makela, R.A. Weinberg, and T. Jacks. 1996. Altered cell cycle kinetics, gene expression, and $\mathrm{G} 1$ restriction point regulation in $\mathrm{Rb}$-deficient fibroblasts. Mol. Cell. Biol. 16: 2402-2407.

Hiebert, S.W., S.P. Chellappan, J.M. Horowitz, and J.R. N evins. 1992. The interaction of $\mathrm{pRb}$ with E2F inhibits the transcriptional activity of E2F. Genes \& Dev. 6: 177-185.

Hiebert, S.W., G. Packham, D.K. Strom, R. Haffner, M. Oren, G. Zambetti, and J.L. Cleveland. 1995. E2F-1:DP-1 induces p53 and overrides survival factors to trigger apoptosis. Mol. Cell. Biol. 15: 6864-6874.

Hijmans, E.M., P.M. Voorhoeve, R.L. Beijersbergen, L. van 't Veer, and R. Bernards. 1995. E2F-5, a new E2F family member that interacts with p130 in vivo. Mol. Cell. Biol. 15: 3082-3089.

Hinds, P.W., S. Mittnacht, V. Dulic, A. Arnold, S.I. Reed, and R.A. Weinberg. 1992. Regulation of retinoblastoma protein functions by ectopic expression of human cyclins. Cell 70: 993-1006.

Hofmann, F., F. M artelli, D.M. Livingston, and Z. Wang. 1996. The retinoblastoma gene product protects E2F-1 from degradation by the ubiquitin-proteasome pathway. Genes \& Dev. 10: 2949-2959.

Hsiao, K.-M., S.L. M cM ahon, and P.J. Farnham. 1994. Multiple DNA el ements are required for the growth regulation of the mouse E2F1 promoter. Genes \& Dev. 8: 1526-1537.

Hsieh, J.-K., S. Fredersdorf, T. Kouzarides, K. Martin, and X. Lu. 1997. E2F1-induced apoptosis requires DN A binding but not transactivation and is inhibited by the retinoblastoma protein through direct interaction. Genes \& Dev. 11: 18401852.

Huet, X., J. Rech, A. Plet, A. Vie, and J.M. Blanchard. 1996. Cyclin A expression is under negative transcriptional control during the cell cycle. Mol. Cell. Biol. 16: 3789-3798.

Hurford, R., D. Cobrinik, M.-H. Lee, and N. Dyson. 1997. pRB and $\mathrm{p} 107 / \mathrm{p} 130$ are required for the regulated expression of different sets of E2F responsive genes. Genes \& Dev. 11: 1447-1463.

Ikeda, M.-A., L. Jakoi, and J. N evins. 1996. A unique role for the $\mathrm{Rb}$ protein in controlling E2F accumulation during cell growth and differentiation. Proc. Natl. Acad. Sci. 93: 32153220.

Ishizaki, J., J.R. N evins, and B.A. Sullenger. 1996. Inhibition of cell proliferation by an RNA ligand that selectively blocks E2F function. Nature Med. 2: 1386-1389.

Ivey-Hoyle, M., R. Conroy, H. Huber, P. Goodhart, A. Oliff, and D.C. Heinbrook. 1993. Cloning and characterization of E2F2, a novel protein with the biochemical properties of transcription factor E2F. Mol. Cell. Biol. 13: 7802-7812.

Jacks, T., A. Fazeli, E. Schmitt, R. Bronson, M. Goodell, and R. Weinberg. 1992. Effects of an Rb mutation in the mouse. Nature 359: 295-300.

Johnson, D.G., J.K. Schwarz, W.D. Cress, and J.R. N evins. 1993. Expression of transcription factor E2F1 induces quiescent cells to enter S phase. Nature 365: 349-352.

Johnson, D.G., W.D. Cress, L. Jakoi, and J.R. Nevins. 1994a. Oncogenic capacity of the E2F1 gene. Proc. Natl. Acad. Sci. 91: 12823-12827.

Johnson, D.G., K. Ohtani, and J.R. N evins. 1994b. Autoregulatory control of E2F-1 expression in response to positive and negative regulators of cell cycle expression. Genes \& Dev. 8: 1514-1525.

Jooss, K., E.W.-F. Lam, A. Bybee, R. Girlin, R. Müller, and N.B. LaThangue. 1995. Proto-oncogenic properties of the DP family of proteins. Oncogene 10: 1529-1536.

Kaelin, W.G., Jr., W. Krek, W.R. Sellers, J.A. DeCaprio, F.
Ajchenbaum, C.S. Fuchs, T. Chittenden, Y. Li, P.J. Farnham, M.A. Blanar, D.M. Livingston, and E.K. Flemington. 1992. Expression cloning of a CDNA encoding a retinoblastomabinding protein with E2F-like properties. Cell 70: 351-364.

Karlseder, J., H. Rotheneder, and E. Wintersberger. 1996. Interaction of Spl with the growth- and cell cycle-regulated transcription factor E2F. Mol. Cell. Biol. 16: 1659-1667.

Kelly, T.J., G.S. Martin, S.L. Forsburg, R.J. Stephen, A. Russo, and P. N urse. 1993. The fission yeast cdc18+ gene product couples S phase to START and mitosis. Cell 74: 371-382.

Kitagawa, M., H. Higashi, I. Suzuki-Takahashi, K. Segawa, S.K. Hanks, Y. Taya, S. Nishimura, and A. Okuyama. 1995. Phosphorylation of E2F-1 by cyclin A-cdk2. Oncogene 10: 229236.

Knudsen, E.S. and J.Y.J. Wang. 1997. Dual mechanisms for the inhibition of E2F binding to RB by cyclin-dependent kinasemediated RB phosphorylation. Mol. Cell. Biol. 17: 57715783.

Kovesdi, I., R. Reichel, and J.R. N evins. 1987. Role of an adenovirus E2 promoter binding factor in E1A-mediated coordinate gene control. Proc. Natl. Acad. Sci. 84: 2180-2184.

Kowalik, T.F., J. DeGregori, J.K. Schwarz, and J.R. N evins. 1995. E2F1 overexpression in quiescent fibroblasts leads to induction of cellular DNA synthesis and apoptosis. J. Virol. 69: 2491-2500.

Krek, W., D.M. Livingston, and S. Shirodkar. 1993. Binding to DNA and the retinoblastoma gene product promoted by complex formation of different E2F family members. Science 262: 1557-1560.

Krek, W., M. Ewen, E., S. Shirodkar, Z, Z. Arany, W.G. Kaelin, and D. Livingston. 1994. N egative regulation of the growthpromoting transcription factor E2F-1 by a stably bound cyclin A-dependent protein kinase. Cell 78: 161-172.

Krek, W., G. Xu, and D.M. Livingston. 1995. Cyclin A-kinase regulation of E2F-1 DNA binding function underlies suppression of an S phase checkpoint. Cell 83: 1149-1158.

La Thangue, N.B. and P.W.J. Rigby. 1987. An adenovirus E1Alike transcription factor is regulated during the differentiation of murine embryonal carcinoma stem cells. Cell 49: 507-513.

Lam, E.W.-F. and R.J. Watson. 1993. An E2F-binding site mediates cell-cycle regulated repression of mouse B-myb transcription. EMBO J. 12: 2705-2713.

Lee, E.Y., C.Y. Chang, N. Hu, Y.C. Wang, C.C. Lai, K. Herrup, W.H. Lee, and A. Bradley. 1992. Mice deficient for Rb are nonviable and show defects in neurogenesis and haematopoiesis. Nature 359: 288-294.

Lee, E.Y.-H.P., N. Hu, S.-S.F. Yuan, L.A. Cox, A. Bradley, W.-H. Lee, and K. Herrup. 1994. Dual roles of the retinoblastoma protein in cell cycle regulation and neuron differentiation. Genes \& Dev. 8: 2008-2021.

Lee, J.-O., A.A. Russo, and N.P. Pavletich. 1998. Structure of the retinoblastoma tumour-suppressor pocket domain bound to a peptide from HPV E7. Nature 391: 859-865.

Lee, M.-H., B.O. Williams, G. Mulligan, S. Mukai, R.T. Bronson, N. Dyson, E. Harlow, and T. Jacks. 1996. Targeted disruption of p107: Functional overlap between p107 and Rb. Genes \& Dev. 10: 1621-1632.

Lees, J.A., M. Saito, M. Vidal, M. Val entine, T. Look, E. Harlow, N. Dyson, and K. Helin. 1993. The retinoblastoma protein binds to a family of E2F transcription factors. Mol. Cell. Biol. 13: 7813-7825.

Leng, X., L. Connell-Crowley, D. Goodrich, and J.W. Harper. 1997. S-phase entry upon ectopic expression of G1 cyclindependent kinases in the absence of retinoblastoma protein phosphorylation. Curr. Biol. 7: 709-712. 
Leone, G., J. DeGregori, Z. Yan, L. Jakoi, R.S. Williams, and J.R. Nevins. 1998. E2F-3 activity is regulated during the cell cycle and is required for the induction of $\mathrm{S}$ phase. Genes \& Dev. (this issue).

Lin, S.-Y., A.R. Black, D. Kostic, S. Pajovic, C.N. Hoover, and J.C. Azizkhan. 1996. Cell cycle-regulated association of E2F1 and Spl is related to their functional interaction. Mol. Cell. Biol. 16: 1668-1675.

Lindeman, G.J., S. Gaubatz, D.M. Livingston, and D. Ginsberg. 1997. The subcellular localization of E2F-4 is cell-cycle de pendent. Proc. Natl. Acad. Sci. 94: 5095-5100.

Lindeman, G.J., L. Dagnino, S. Gaubatz, Y. Xu, R. Bronson, H.B. Warren, and D.M. Livingston. 1998. A specific, nonproliferative role for E2F-5 in choroid plexus function revealed by gene targeting. Genes \& Dev. 12: 1092-1098.

Lukas, J., B.O. Petersen, K. Holm, J. Bartek, and K. Helin. 1996. Deregulated expression of E2F family members induces Sphase entry and overcomes p16 ${ }^{\mathrm{IN} \mathrm{K4A}}$-mediated growth suppression. Mol. Cell. Biol. 16: 1047-1057.

Lukas, J., T. Herzinger, K. Hansen, M.C. Moroni, D. Resnitzky, K. Helin, S.I. Reed, and J. Bartek. 1997. Cyclin E-induced S phase without activation of the pRb/E2F pathway. Genes \& Dev. 11: 1479-1492.

Luo, R.X., A.A. Postigo, and D.C. Dean. 1998. Rb interacts with histone deacetylase to repress transcription. Cell 92: 463473.

Macleod, K.F., Y. Hu, and T. Jacks. 1996. Loss of RB activates both p53-dependent and independent cell death pathways in the developing mouse nervous system. EMBO J. 15: 61786188.

Magae, J., C.-L. Wu, S. Illenye, E. Harlow, and N.H. Heintz. 1996. N uclear localization of DP and E2F transcription factors by heterodimeric partners and retinoblastoma protein family members. J. Cell Sci. 109: 1717-1726.

Magnaghi-Jaulin, L., R. Groisman, I. Naguibneva, P. Robin, S. Lorain, J.P. Le Villain, F. Troalen, D. Trouche, and A. HarelBellan. 1998. Retinoblastoma protein represses transcription by recruiting a histone deacetylase. Nature 391: 601-604.

Mann, D.J. and N.C. Jones. 1996. E2F-1 but not E2F-4 can overcome p16-induced G1 cell cycle arrest. Curr. Biol. 6: 474483.

Martin, K., D. Trouche, C. Hagemeier, T.S. Sorensen, N.B. La Thangue, and T. Kouzarides. 1995. Stimulation of E2F1/DP1 transcriptional activity by MDM2 oncoprotein. Nature 375: 691-694.

M eans, A.L., J.E. Slansky, S.L. M cM ahon, M.W. Knuth, and P.J. Farnham. 1992. The HIP binding site is required for growth regulation of the dihydrofolate reductase promoter. Mol. Cell. Biol. 12: 1054-1063.

Mittnacht, S. 1998. Control of pRB phosphorylation. Curr. Opin. Genet. Dev. 8: 21-27.

M oberg, K., M .A. Starz, and J.A. Lees. 1996. E2F-4 switches from p130 to p107 and pRB in response to cell cycle reentry. Mol. Cell. Biol. 16: 1436-1449.

M orgenbesser, S.D., B.O. Williams, T. Jacks, and R.A. De Pinho. 1994. p53 dependent apoptosis produced by Rb-deficiency in the developing lens. Nature 371: 72-74.

Morkel, M., J. Wenkel, A.J. Bannister, T. Kouzarides, and C. Hagemeier. 1997. An E2F-like repressor of transcription. Nature 390: 567-568.

Mudryj, M., S.H. Devoto, S.W. Hiebert, T. Hunter, J. Pines, and J.R. N evins. 1991. Cell cycle regulation of the E2F transcription factor involves an interaction with cyclin A. Cell 65: 1243-1253.

M üller, H., M. M oroni, E. Vigo, B.O. Peterson, J. Bartek, and K. Helin. 1997. Induction of S-phase entry by E2F transcription factors depends on their nuclear local ization. Mol. Cell. Biol. 17: 5508-5520.

Mulligan, G. and T. Jacks. 1998. The retinoblastoma gene family: Cousins with overlapping interests. Trends Genet. (in press).

Mulligan, G.J., J. Wong, and T. Jacks. 1998. p130 is dispensable in peripheral $\mathrm{T}$ Iymphocytes: Evidence for functional compensation by p107 and p130. Mol. Cell. Biol. 18: 206-220.

N eufeld, T.P., A.F.A. de la Cruz, L.A. Johnston, and B.A. Edgar. 1998. Coordination of cell growth and division by Drosophila E2F. Cell (in press).

Neuman, E., E.K. Flemington, W.R. Sellers, and W.G. Kaelin. 1994. Transcription of the E2F1 gene is rendered cell cycle dependent by E2F DNA binding sites within its promoter. Mol. Cell. Biol. 14: 6607-6615.

O'Connor, D.J., E.W.-F. Lam, S. Griffin, S. Zhong, L.C. Leighton, S.A. Burbidge, and X. Lu. 1995. Physical and functional interactions between $\mathrm{p} 53$ and cell cycle co-operating transcription factors, E2F1 and DP1. EMBO J. 14: 6184-6192.

Ogris, E., H. Rotheneder, I. Mudrak, A. Pichler, and E. Wintersberger. 1993. A binding site for transcription factor E2F is a target for trans activation of murine thymidine kinase by polyomavirus large $T$ antigen and plays an important role in growth regulation of the gene. J. Virol. 67: 1765-1771.

Ohtani, K. and J.R. Nevins. 1994. Functional properties of a Drosophila homolog of the E2F1 gene. Mol. Cell. Biol. 14: 1603-1612.

Ohtani, K., J. DeGregori, and J.R. N evins. 1995. Regulation of the cyclin E gene by transcription factor E2F1. Proc. Natl. Acad. Sci. 92: 12146-12150.

Ohtani, K., J. DeGregori, G. Leone, D.R. Herendeen, T.J. Kelly, and J.R. N evins. 1996. Expression of the HsOrcl gene, a human ORC 1 homolog is regulated by cell proliferation via the E2F transcription factor. Mol. Cell. Biol. 16: 6977-6984.

Ormondroyd, E., S. de la Luna, and N.B. La Thangue. 1995. A new member of the DP family, DP-3, with distinct protein products suggests a regulatory role for al ternative spl icing in the cell cycle transcription factor DRTF1/E2F. Oncogene 11: 1437-1446.

Pasteau, S., L. Loiseau, L. Arnaud, A. Trembleau, and G. Brun. 1995. Isolation and characterization of a chicken homolog of the E2F-1 transcription factor. Oncogene 11: 1475-1486.

Pearson, B.E., H.P. N asheuer, and T.S. Wang. 1991. Human DNA polymerase $\alpha$ gene: Sequences controlling expression in cycling and serum-stimulated cells. Mol. Cell. Biol. 11: 2081-2095.

Phillips, A.C., S. Bates, K.M. Ryan, K. Helin, and K.H. Vousden. 1997. Induction of DNA synthesis and apoptosis are separable functions of E2F-1. Genes \& Dev. 11: 1853-1863.

Philpott, A. and S.H. Friend. 1994. E2F and its developmental regulation in Xenopus laevis. Mol. Cell. Biol. 14: 5000-5009.

Piatti, S., C. Lengauer, and K. N asmyth. 1995. Cdc6 is an unstable protein whose de novo synthesis in $\mathrm{G} 1$ is important for the onset of S-phase and for preventing a "reductional" anaphase in the budding yeast Saccharomyces cerevisiae. EMBO J. 14: 3788-3799.

Pierce, A.M., S.M. Fisher, C.J. Conti, and D.G. Johnson. 1998. Deregulated expression of E2F1 induces hyperplasia and cooperates with ras in skin tumor development. Oncogene 16: 1267-1276.

Pomerantz, J., N . Schrei ber-Agus, N .J. Li egeois, A. Silverman, L. Alland, L. Chin, J. Potes, K. Chen, I. Orlow, H.-W. Lee, C. Cordon-Cardo, and R. DePinho. 1998. The ink4a tumor suppressor gene product, p19ARF, interacts with MDM2 and neutralizes MDM2's inhibition of p53. Cell 92: 713-723.

Qian, Y., C. Luckey, L. Horton, M. Esser, and D.J. Templeton. 
1992. Biological function of the retinoblastoma protein re quires distinct domains for hyperphosphorylation and transcription factor binding. Mol. Cell. Biol. 12: 5363-5372.

Qian, Y.W., Y.C. Wang, R.E. Hollingsworth, Jr., D. Jones, N. Ling, and E.Y. Lee. 1993. A retinoblastoma-binding protein related to a negative regulator of Ras in yeast. Nature 364: 648-652.

Qin, X.-Q., D.M. Livingston, W.G. Kaelin, Jr., and P. Adams. 1994. Deregulated transcription factor E2F-1 expression leads to S-phase entry and p53-mediated apoptosis. Proc. Natl. Acad. Sci. 91: 10918-10922.

Qin, X.-Q., D.M. Livingston, M. Ewen, W.R. Sellers, Z. A rany, and W.G. Kaelin. 1995. The transcription factor E2F-1 is a downstream target of RB action. Mol. Cell. Biol. 15: 742755.

Rogers, K.T., P.D.R. Higgins, M.M. Milla, R.S. Phillips, and J.M . Horowitz. 1996. DP-2, a heterodimeric partner of E2F: Identification and characterization of DP-2 proteins expressed in vivo. Proc. Natl. Acad. Sci. 93: 7594-7599.

Royzman, I., A.J. Whittaker, and T.L. Orr-Weaver. 1997. Mutations in Drosophila DP and E2F distinguish $\mathrm{G}_{1}-\mathrm{S}$ progression from an associated transcriptional program. Genes \& Dev. 11: 1999-2011.

Saito, M., K. Helin, M.B. Valentine, B.B. Griffith, C.L. Willman, E. Harlow, and A.T. Look. 1995. Amplification of the E2F1 transcription factor gene in the HEL erythroleukemia cell line. Genomics 25: 130-138.

Sardet, C., M. Vidal, D. Cobrinik, Y. Geng, C. Onufryk, A. Chen, and R.A. Weinberg. 1995. E2F-4 and E2F-5, two novel members of the E2F family, are expressed in the early phases of the cell cycle. Proc. Natl. Acad. Sci. 92: 2403-2407.

Sardet, C., L. LeCam, E. Fabbrizio, and M. Vidal. 1997. E2Fs and the retinoblastoma protein family. In Oncogenes as transcriptional regulators (ed. J. Ghysdael and M. Yaniv), Vol. 2, pp. 1-63. Birkhauser Verlag, Berlin, Germany.

Schulze, A., K. Zerfass, D. Spitkovsky, S. Middendorp, J. Berges, K. Helin, P. Jansen-Dürr, and B. Henglein. 1995. Cell cycle regulation of the cyclin $A$ gene promoter is mediated by a variant E2F site. Proc. Natl. Acad. Sci. 92: 11264-11268.

Schwarz, J.K., S.H. Devoto, E.J. Smith, S.P. Chellappan, L. Jakoi, and J.R. N evins. 1993. Interactions of the p107 and Rb proteins with E2F during the cell proliferation response. EMBO J. 12: 1013-1020.

Schwarz, J.K., C.H. Bassing, I. Kovesdi, M.B. Datto, M. Blazing, S. George, X. Wang, and J.R. N evins. 1995. Expression of the E2F1 transcription factor overcomes TGF- $\beta$ mediated growth suppression. Proc. Natl. Acad. Sci. 92: 483-487.

Sears, R., K. Ohtani, and J.R. N evins. 1997. Identification of positively and negatively acting el ements regulating expression of the E2F2 gene in response to cell growth signals. Mol. Cell. Biol. 17: 5227-5235.

Sellers, W.R., J.W. Rodgers, and W.G. Kaelin, Jr. 1995. A potent transrepression domain in the retinoblastoma protein induces a cell cycle arrest when bound to E2F sites. Proc. Natl. Acad. Sci. 92: 11544-11548.

Sellers, W.R., B.G. N ovitch, S. Miyake, A. Heith, G.A. Otterson, F.J. Kaye, A.B. Lassar, and W.G. Kaelin, Jr. 1998. Stable binding to E2F is not required for the retinoblastoma protein to activate transcription, promote differentiation, and suppress tumor cell growth. Genes \& Dev. 12: 95-106.

Shan, B. and W.-H. Lee. 1994. Deregulated expression of E2F-1 induces S-phase entry and leads to apoptosis. Mol. Cell. Biol. 14: 8166-8173.

Shan, B., X. Zhu, P.-L. Chen, T. Durfee, Y. Yang, D. Sharp, and W.-H. Lee. 1992. M olecular cloning of cellular genes encoding retinoblastoma-associated proteins: Identification of a gene with properties of the transcription factor E2F. Mol. Cell. Biol. 12: 5620-5631.

Shan, B., T. Durfee, and W.-H. Lee. 1996. Disruption of RB/ E2F-1 interaction by single point mutations in E2F-1 enhances S-phase entry and apoptosis. Proc. Natl. Acad. Sci. 93: 679-684.

Shirodkar, S., M. Ewen, J.A. DeCaprio, J. M organ, D.M. Livingston, and T. Chittenden. 1992. The transcription factor E2F interacts with the retinoblastoma product and a p107-cyclin A complex in a cell cycleregulated manner. Cell 68: 157166.

Singh, P., S.H. Wong, and W. Hong. 1994. Overexpression of E2F-1 in rat embryo fibroblasts leads to neoplastic transformation. EMBO J. 13: 3329-3338.

Singh, P., J. Coe, and W. Hong. 1995. A role for retinoblastoma protein in potentiating transcriptional activation by the glucocorticoid receptor. Nature 374: 562-565.

Slansky, J.E. and P.J. Farnham. 1996. Transcriptional regulation of the dihydrofolate reductase gene. BioEssays 18: 55-62.

Smith, E.J., G. Leone, J. DeGregori, L. Jakoi, and J.R. N evins. 1996. The accumulation of an E2F-p130 transcriptional repressor distinguishes a G0 cell state from a G1 cell state. Mol. Cell. Biol. 16: 6965-6976.

Sorensen, T.S., R. Girling, C.W. Lee, J. Gannon, L.R. Bandara, and N.B. La Thangue. 1996. Functional interaction between DP-1 and p53. Mol. Cell. Biol. 16: 5888-5895.

Tao, Y., R.F. Kassatly, W.D. Cress, and J.M. Horowitz. 1997. Subunit composition determines E2F DNA-binding site specificity. Mol. Cell. Biol. 17: 6994-7007.

Taunton, J., C.A. Hassig, and S.L. Schreiber. 1996. A mammalian histone deacetylase related to the yeast transcriptional regulator Rpd3p. Science 272: 408-411.

Tevosian, S.G., K.E. Paulson, R. Bronson, and A.S. Yee. 1996. Expression of the E2F-1/DP-1 transcription factor in murine development. Cell Growth Differ. 7: 43-52.

Tommasi, S. and G.P. Pfeifer. 1995. In vivo structure of the human cdc2 promoter: Release of a p130-E2F-4 complex from sequences immediately upstream of the transcription initiation site coincides with the induction of cdc2 expression. Mol. Cell. Biol. 15: 6901-6913.

Trimarchi, J.M., B. Fairchild, R. Verona, K. Moberg, N. Andon, and J.A. Lees. 1998. E2F-6, a member of the E2F family that can behave as a transcriptional repressor. Proc. Natl. Acad. Sci. 95: 2850-2855.

Trouche, D. and T. Kouzarides. 1996. E2F1 and E1A 12S have a homologous activation domain regulated by $\mathrm{RB}$ and CBP. Proc. Natl. Acad. Sci. 93: 1439-1442.

Trouche, D., C. Le Chalony, C. Muchardt, M. Yaniv, and T. Kouzarides. 1997. RB and hbrm co-operate to repress the activation functions of E2F-1. Proc. Natl. Acad. Sci. 94: 11268-11273.

Verona, R., K. M oberg, S. Estes, M. Starz, J.P. Vernon, and J.A. Lees. 1997. E2F activity is regulated by cell-cycle-dependent changes in subcellular localization. Mol. Cell. Biol. 17: 7268-7282.

Wade, M., T.F. Kowalik, M. Mudryj, E.S. Huang, and J.C. Azizkhan. 1992. E2F mediates dihydrofolate reductase promoter activation and multiprotein complex formation in human cytomegal ovirus infection. Mol. Cell. Biol. 12: 4364-4374.

Weinberg, R.A. 1996. E2F and cell proliferation: A world turned upside down. Cell 85: 457-459.

Weintraub, S.J., C.A. Prater, and D.C. Dean. 1992. Retinoblastoma protein switches the E2F site from positive to negative element. Nature 358: 259-261.

Weintraub, S.J., K.N.B. Chow, R.X. Luo, S.H. Zhang, S. He, and D.C. Dean. 1995. Mechanism of active transcriptional re- 
pression by the retinoblastoma protein. Nature 375: 812815.

Welch, P.J. and J.Y.J. Wang. 1993. A C-terminal protein-binding domain in the retinoblastoma protein regulates nuclear $\mathrm{C}-$ Abl tyrosine kinase in the cell cycle. Cell 75: 779-790.

- - . 1995. Disruption of retinoblastoma protein function by coexpression of its $C$ pocket fragment. Genes \& Dev. 9: 3146.

Whyte, P., K.J. Buchkovich, J.M . Horowitz, S.H. Friend, M. Raybuck, R.A. Weinberg, and E. Harlow. 1988. Association be tween an oncogene and an anti-oncogene: The adenovirus ElA proteins bind to the retinoblastoma gene product. $\mathrm{Na}$ ture 334: 124-129.

Whyte, P., N.M. Williamson, and E. Harlow. 1989. Cellular targets for transformation by the adenovirus E1A proteins. Cell 56: 67-75.

Williams, R.S., R.V. Sholet, and B. Stillman. 1997. A human protein related to yeast Cdc6. Proc. Natl. Acad. Sci. 94: 142147.

Wu, C.-L., L.R. Zukerberg, C. N gwu, E. Harlow, and J.A. Lees. 1995. In vivo association of E2F and DP family proteins. Mol. Cell. Biol. 15: 2536-2546.

Wu, C.-L., M. Classon, N. Dyson, and E. Harlow. 1996. Expression of dominant-negative mutant DP-1 blocks cell cycle progression in G1. Mol. Cell. Biol. 16: 3698-3706.

Wu, X. and A.J. Levine. 1994. p53 and E2F-1 cooperate to me diate apoptosis. Proc. Natl. Acad. Sci. 91: 3602-3606.

Xu, G., D.M. Livingston, and W. Krek. 1995. Multiple members of the E2F transcription factor family are the products of oncogenes. Proc. Natl. Acad. Sci. 92: 1357-1361.

Xu, M., K.A. Sheppard, C.Y. Peng, A.S. Yee, and H. PiwnicaWorms. 1994. Cyclin A/CDK2 binds directly to E2F-1 and inhibits the DNA-binding activity of E2F-1/DP-1 by phosphorylation. Mol. Cell. Biol. 14: 8420-8431.

Yamasaki, L. 1998. Growth Regulation by the E2F and DP transcription factor families. In Cell cycle control (ed. M. Pagano), pp. 199-227. Springer, New York, NY.

Yamasaki, L., T. Jacks, R. Bronson, E. Goillot, E. Harlow, and N . Dyson. 1996. Tumor induction and tissue atrophy in mice lacking E2F-1. Cell 85: 537-548.

Yamasaki, L., R. Bronson, B.O. Williams, N .J. Dyson, E. Harlow, and T. Jacks. 1998. Loss of E2F-1 reduces tumorigenesis and extends lifespan of $\mathrm{Rbl}(+/-)$ mice. Nature Genet. 18: 360364.

Yan, Z., J. DeGregori, R. Shohet, G. Leone, B. Stillman, J.R. N evins, and R.S. Williams. 1998. Cdc6 is regulated by E2F, and is essential for DNA replication in mammalian cells. Proc. Natl. Acad. Sci. 95: 3603-3608.

Yee, A.S., R. Reichel, I. Kovesdi, and J.R. Nevins. 1987. Promoter interaction of the E1A-inducible factor E2F and its potential role in the formation of a multi-component complex. EMBO J. 6: 2061-2068.

Zamanian, M. and N.B. La Thangue. 1993. Transcriptional repression by the Rb-related protein p107. Mol. Biol. Cell 4: 389-396.

Zhang, Y. and S.P. Chellappan. 1995. Cloning and characterization of human DP2, a novel dimerization partner of E2F. Oncogene 10: 2085-2093.

Zhang, Y., Y. Xiong, and W.G. Yarbrough. 1998. ARF promotes MDM 2 degradation and stabilizes p53: ARF-KNK4a locus del etion impairs both the Rb and p53 tumor suppressor pathways. Cell 92: 725-734.

Zhu, L., S. van den Heuvel, K. Helin, A. Fattaey, M. Ewen, D. Livingston, N. Dyson, and E. Harlow. 1993. Inhibition of cell proliferation by p107, a relative of the retinoblastoma protein. Genes \& Dev. 7: 1111-1125.
Zhu, L., L. Zhu, E. Xie, and L.-S. Chang. 1995. Differential roles of two tandem E2F sites in repression of the human p107 promoter by retinoblastoma and other proteins. Mol. Cell. Biol. 15: 3552-3562.

Zindy, F., C.M. Eischen, D.H. Randle, T. Kamijo, J.L. Cleveland, C.J. Sherr, and M.F. Roussel. 1998. MYC signaling via the ARF tumor suppressor regulates p53-dependent apoptosis and immortalization. Genes \& Dev. (this issue).

Zwicker, J., N. Liu, K. Engeland, F.C. Lucibello, and R. M üller. 1996. Cell cycle regulation of E2F site occupation in vivo. Science 271: 1595-1597. 


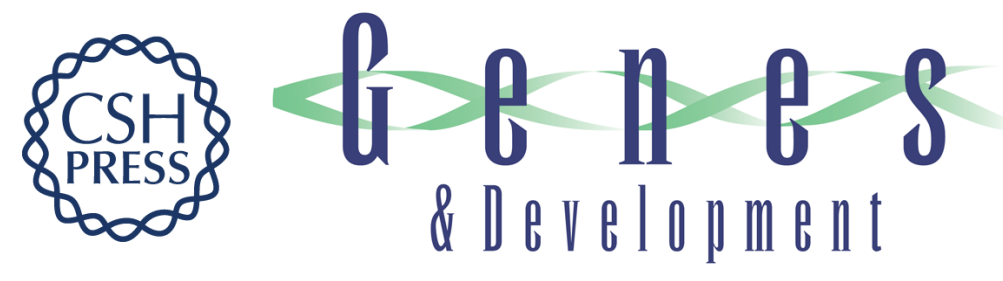

\section{The regulation of E2F by pRB-family proteins}

Nicholas Dyson

Genes Dev. 1998, 12:

Access the most recent version at doi:10.1101/gad.12.15.2245

References This article cites 188 articles, 111 of which can be accessed free at: http://genesdev.cshlp.org/content/12/15/2245.full.html\#ref-list-1

License

Email Alerting Receive free email alerts when new articles cite this article - sign up in the box at the top Service right corner of the article or click here.

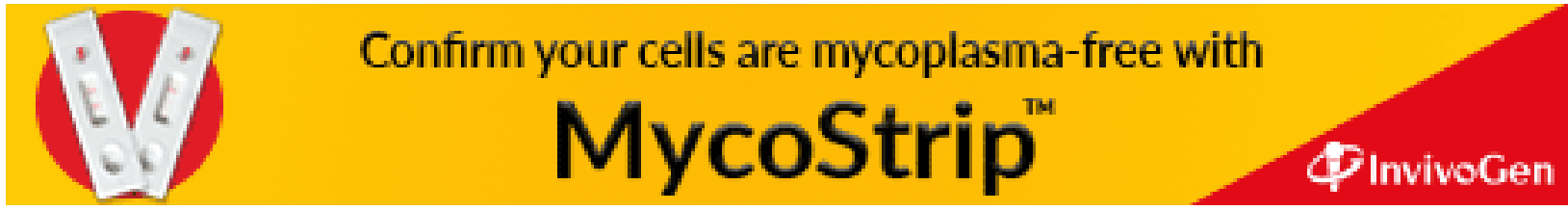

